\title{
Rice (Oryza Sativa L.) Whole Grain Genome-Wide Association Study for Neutral Sugar Content
}

Rahele Panahabadi

Shahid Beheshti University

Lauren S. McKee

Royal Institute of Technology: Kungliga Tekniska Hogskolan

Asadollah Ahmadikhah ( $\sim$ a_ahmadikhah@sbu.ac.ir)

Shahid Beheshti University https://orcid.org/0000-0001-5100-9740

Pär K. Ingvarsson

Swedish University of Agricultural Sciences: Sveriges lantbruksuniversitet

Naser Farrokhi

Shahid Beheshti University

\section{Original article}

Keywords: genomic scan, HPAECD-PAD, monosaccharide, quantitative trait loci (QTL), single nucleotide polymorphism (SNP)

Posted Date: June 8th, 2021

DOI: https://doi.org/10.21203/rs.3.rs-575013/v1

License: () (1) This work is licensed under a Creative Commons Attribution 4.0 International License. Read Full License 


\section{Abstract}

Background Cell wall matrix polysaccharides are structurally complex and diverse, but our knowledge about their synthesis is limited. The building blocks (monosaccharides) of these polysaccharides have critical role in defining the number and the ultrastructure (size) of rice grains, and therefore would have great influence on seed vigor, yield and quality. Genome-wide association study (GWAS) is a method of choice for fine mapping of QTLs involved in defining plant cell wall structure and modifications. The monosaccharides that contribute to major cell wall matrix polysaccharides in whole grains of 197 rice accessions were quantified using acid hydrolysis and high-performance anion-exchange chromatography with pulsed amperometric detection. A GWAS of calculated monosaccharide content in rice whole grain (RWG) was carried out using 33,812 single-nucleotide polymorphisms (SNPs) to identify corresponding markers in $200 \mathrm{kbp}$ flanking regions.

Results In total, 49 significant SNPs contained in 19 genomic regions (QTLs) on eight chromosomes of rice were determined to be associated with monosaccharides content. The candidate genes in QTL regions included the following: arabinose content was associated with a- $N$-arabinofuranosidase, pectinesterase inhibitor, a glycoside hydrolase (GH) from family 16 (GH16 enzyme); xylose content was associated with ethylene-responsive element-binding protein and a pyruvate kinase; mannose content was associated with a MYB family transcription factor and S-domain receptor-like protein kinase; galactose content was associated with a glycocyltransferase (GT) from family 8 (GT8 enzyme), GRAS family transcription factor, glutathione S-transferase, GH16 and GH17 enzymes; fucose content was associated with a GH16 enzyme, lysine-rich arabinogalactan protein 19 and a receptor protein kinase; and finally rhamnose content was associated with OSFBX41, pectinesterase, COBRA-like protein, and OsSAUR13 (Auxin-responsive SAUR).

Conclusion The results of this study should improve our understanding of the genetic basis of the factors that might be involved in the biosynthesis and turnover of major matrix polysaccharides present in RWG. Several QTLs were identified on different chromosomes, all are reported for first. Further, our data provide insight that will be useful in the design of future breeding programs, allowing breeders to use available genetic resources more effectively in meeting global food demand and supply.

\section{Background}

Rice (Oryza sativa L.) is an important crop and also a model system for grass cell wall research with a completely sequenced genome and many available genetic resources (Li et al. 2018). Rice whole grain (RWG) consists of an outer protective covering, the hull, and the caryopsis. The caryopsis consists of pericarp outer layers, seed-coat, embryo (germ), and the endosperm (Juliano 2016; Upadhyay and Karn 2018). Most rice by-products, including rice husk and bran [a-cellulose (25-35 wt\%), hemicellulose (18-21 wt\%), lignin (23-31 wt\%) and silica (15 - 17 wt\%); Razavi-Nouri et al. 2006], are used to produce silicon compounds (Della et al. 2002; Zemke and Wood, 2009) and animal feed (Bodie et al. 2019). The other applications of rice husk can be enumerated as thermal insulator, fuel, polymer filler and additive, and absorbant of phenol, pigments, dyes and heavy metals (Ajmal et al. 2003; Kumar et al. 2006; Bera and Kale, 2008; Vidal et al. 2009; Yussuf et al. 2010). Brewer's rice, which is a mixture of broken rice, rice bran, and rice germ, is also used almost exclusively in the production of beer and sake (Esa et al. 2013; Okuda 2019). In recent years, rice by-products have received increased attention as functional foods due to their phenolic-based compounds, in addition to having high amounts of vitamins, minerals, and fiber, an anti-atherogenic substance that can help to lower cholesterol levels (Wilson et al. 2002). The endosperm in RWG consists of the aleurone layer and the endosperm proper, consisting of the sub-aleurone layer and the starchy or inner endosperm (Xu et al. 2016). Rice endosperm cells, as in other members of the Poaceae, comprise up to $70 \%$ starch, which is used for energy storage and is absent in the cell wall itself (Moongngarm et al. 2012). Rice bran is typically removed before rice is sold for human consumption; the bran consists of $\sim 8 \%$ of the initial grain weight and is comprised $~ 80 \%$ with carbohydrates (Gul et al. 2015) that mostly consist of cellulose, matrix polysaccharides, and pectin (Saunders et al. 1985). Grass cell walls provide abundant sources of dietary fibers for human consumption and biomass for the industrial production of renewable energy (Saldívar et al. 2020). All of these varied carbohydrate-rich parts of the rice grain receive their properties from the monosaccharide contents that are the building blocks of cell walls and starch. We explored genomic associations with rice starch content in a previous publication (Panahabadi et al., 2021).

Rice grain cell walls are composites of polysaccharides, with cellulose as a fibrous component and so-called matrix polysaccharides (xylans and glucans) embedded in a pectic gel, alongside lignin, other phenolics, and some proteoglycans (Palmer et al. 2015). Rice xylans include glucuronoarabinoxylan and arabinoxylan (Ebringerova et al. 2005). Structurally, these heteroxylans bear a backbone of 1,4-linked-B-D-xylopyranosyl residues with a variety of mono-/oligosaccharide decorations (Kozlova et al. 2014; Jacquemin et al. 2015; Shrotri et al. 2017). Mixed-linkage $\beta$-glucans (MLG) and xyloglucans define the major glucan contents of RWG, aside from cellulose (Panahabadi et al., 2021). Rice grains contain more pectin than other grains (Shibuya and Nakane, 1984; Palmer et al. 2015). Pectin (for 
review on structure and classification in Poaceae see Bouchet et al. 2014; Ahmed et al. 2017) is built of a series of complex linear polymers of $\mathrm{a}-(1 \rightarrow 4)$-D-galacturonic acid with occasional rhamnopyranosyl residues, and additional polymers rich in arabinose and galactose (Hachem et al. 2016). Arabinan and arabinoglactans are a major location for arabinose monosaccharide found in rice grain (Palmer et al. 2015), with the remaining small portion of arabinose found in cell wall xylan.

Over the last decade, the availability of draft genome sequences for the majority of the world's major crops in combination with genome wide association studies (GWAS) has revolutionized our path towards gene discovery for improved crop breeding. For instance, in a quantitative trait loci (QTL) mapping in grains of doubled haploid rice (a cross between Japonica and Indica), total soluble sugars were measured to be higher in Japonica with 17 QTLs being associated (Yang et al., 2014). Here, the results from a newly performed GWAS are presented to identify genes involved in the biosynthesis, turnover and/or transport of monosaccharides in RWG, using a wide diversity of rice accessions. An understanding of the natural variability of monosaccharide content in rice and their association with particular loci can greatly contribute to the identification of candidate genes involved in biosynthesis of major RWG polysaccharides. Our data could provide markers to enhance the nutritional value and impact the related industries as being used in targeted breeding programs.

\section{Materials And Methods}

\section{Materials}

Arabinose, xylose, galactose, mannose, rhamnose, fucose, sodium azide, and myo-inositol were purchased from Sigma Aldrich (Berlin, Germany). Trifluoroacetic acid (TFA) was from Merck (Berlin, Germany). The solution of $50 \% \mathrm{NaOH}$ used for HPAEC-PAD analysis was obtained from Fisher Scientific (Berlin, Germany).

\section{Cultivation of Rice Accessions}

The seeds of rice accessions (197 genotypes, as described in Supplementary Table S1) were obtained from the International Rice Research Institute (IRRI), Philippines. The seeds were grown as described previously (Panahabadi et al. 2021), planted in plots of $2 \times 2$ $\mathrm{m}^{2}$ with $25 \mathrm{~cm}$ within rows spacing at Sari Agricultural University, Iran during the 2017-2019 cultivation season. The accessions used consisted of a mixture of landraces, breeding lines, varieties, and cultivars. The genotypes were evaluated using a randomized complete design with three replications. Land was fertilized using superphosphate triple $(180 \mathrm{hg} / \mathrm{ha})$ and potash $(80 \mathrm{~kg} / \mathrm{ha})$ at the plowing stage, and urea $(180 \mathrm{hg} / \mathrm{ha})$ at the seedling stage. All seeds were harvested at maturity and were subsequently stored in dry conditions at $4{ }^{\circ} \mathrm{C}$.

The accessions were from the following sub-populations (as defined by Zhao et al. 2011): TEJ (Temperate Japonica), IND (Indica), AUS (aus), ARO (Aromatic), TRJ (Tropical Japonica) and ADMIX. Data from the rice $44.1 \mathrm{~K}$ SNP array was downloaded for all accessions from the Gramene portal (http://gramene.org). Their genotyping by high-quality custom-designed 44,100 oligonucleotide genotyping array reported on 44.1K SNPs (Zhao et al. 2011). Single seed descent was performed on all genotypes in the subsequent year that followed with phenotyping. Plots were hand harvested at maturity and grains were stored at $4{ }^{\circ} \mathrm{C}$. Using the sample miller, the grain was ground to a fine powder, passed through a 0.1 -micron sieve and the flour were stored at $4{ }^{\circ} \mathrm{C}$.

\section{Genotyping by Sequencing and Imputation Method}

The development and sequencing of a SNP array hybridization for the rice population have previously been described by Zhao et al. (2011). Briefly, 44,100 SNPs from two data sources, i.e., OryzaSNP project and OMAP project, were used for GWAS. In the designed experiments, BioPrime DNA labeling kit (Invitrogen, Cat. No: 18094-011) was used to generate the probe that used for hybridization purposes according to Affymetrix SNP 6.0 protocol.

\section{Monosaccharide Content Analysis}

RWG flour ( 1 mg per accession) was used for monosaccharide analysis using the method described by Zhang et al. (2012a). Briefly, flour was incubated with $1 \mathrm{ml} 2 \mathrm{M}$ TFA for $3 \mathrm{~h}$ at $120^{\circ} \mathrm{C}$. The monosaccharides released were separated by HPAEC-PAD on a Dionex ICS 3000. The reaction mixtures were diluted in deionized water $(1: 10 \mathrm{v} / \mathrm{v})$. The released monosaccharides were resolved using a Dionex ICS 3000 HPAEC-PAD (high-performance liquid chromatography with pulsed amperometric detection) operated by Chromeleon software version 6.80 (Dionex) using a Dionex CarboPac PA1 column maintained at $30^{\circ} \mathrm{C}$ at a flow rate of $1 \mathrm{~mL} \mathrm{~min}^{-1}$. Samples were injected at a $10 \mu \mathrm{l}$ volume. Solvent $A$ was water, solvent $B$ was $1 \mathrm{M}$ sodium hydroxide, solvent $\mathrm{C}$ was $200 \mathrm{mM}$ sodium hydroxide with $170 \mathrm{mM}$ sodium acetate, and solvent $\mathrm{D}$ was $1 \mathrm{M}$ sodium acetate. For the detection of glucose monosaccharides, the following gradient was 
employed: prewash and column calibration, $-5-0$ min $15 \% \mathrm{~B}\left(0.5 \mathrm{ml} \mathrm{min}^{-1}\right)$; sample injection, $0-16 \mathrm{~min} 15 \% \mathrm{~B}\left(0.5 \mathrm{ml} \mathrm{min}^{-1}\right)$; gradient elution, $15-30 \mathrm{~min} 33 \% \mathrm{~B}\left(0.5 \mathrm{ml} \mathrm{min}^{-1}\right), 30-31 \mathrm{~min} 33 \% \mathrm{~B}$ and $50 \% \mathrm{D}\left(0.5 \mathrm{ml} \mathrm{min}^{-1}\right)$; column wash and final elution, 31-35 min 15\% $\mathrm{B}$ $\left(0.5 \mathrm{ml} \mathrm{min}^{-1}\right)$. The amount of each monosaccharide was identified and quantified by comparison with the retention times and peak areas of neutral monosaccharide standards. Broad-sense heritability $\left(\mathrm{H}_{\mathrm{b}}{ }^{2}\right)$ of monosaccharides was estimated from the phenotypic data using rptR package (McCullagh and Nelder 1989).

\section{Genome-wide Association Mapping}

Association analyses were performed using 33,812 SNPs with a minor allele frequency (MAF) above $5 \%$ and phenotyping data obtained from 197 accessions, using GAPIT (Lipka et al. 2012) with the Blink model (Huang et al, 2019). BLINK model has high statistical power and less false positives (Huang et al, 2019). The kinship matrix was obtained at TASSEL v.5, and heatmap of the kinship matrix was produced in GAPIT (Zhang et al. 2010).

\section{Bioinformatics and Gene Identification}

In order to identify genes underlying the QTLs of monosaccharide content that overlapped with the genomic regions (i.e., their associated SNPs), genes deposited on the Rice Annotation Project database (http://rice.plantbiology.msu.edu/) and also IRGSP-1.0 (https://rapdb.dna.affrc.go.jp/) were assessed. All hypothetical genes were ignored in order to put protein coding sequences and transposable elements into prospect for further analyses. We searched for genes in an interval of $100 \mathrm{~kb}$ in either direction from SNP markers that flanked our QTLs (i.e., a total of $200 \mathrm{~kb}$ ) in order to account for map order uncertainty and LD. The $200 \mathrm{~Kb}$ window was chosen based on LD decay in rice (Mather et al. 2007). To ascertain whether candidate genes underlying our QTLs were previously cloned and functionally annotated, a thorough literature search was made for each of the genes. In addition, co-expression analysis of the genes was carried out to establish their relationship to the genes that are involved in cell wall biosynthesis, modification and hydrolysis at Genevestigator (https://genevestigator.com/). Evidences of gene expression in different tissues obtained from Rice Genome Annotation Project (http://rice.plantbiology.msu.edu/). RiceFrend (https://ricefrend.dna.affrc.go.jp) was used for identification of co-expressed genes. Gene ontology (GO) analysis was conducted using PANTHER (http://pantherdb.org/) and KEGG database (https://www.kegg.jp/) was used for investigating key metabolic pathways.

\section{Results}

\section{Phenotypic Variation in Rice Accessions}

Our rice collection consisted of 197 rice accessions was collected from 64 countries (Supplementary Table S1) and the grain from these accessions was previously analyzed by GWAS to understand the genetic control of starch and $(1,3 ; 1,4)$ - $\beta$-glucan content in grain (Panahabadi et al. 2021) Our new analyses present monosaccharide composition for whole grain in the same accessions, quantifying the neutral sugars (arabinose, xylose, mannose, galactose, fucose, and rhamnose). The traits mostly showed a normal distribution between samples, except for mannose and rhamnose that skewed towards lower values, and fucose that skewed towards higher values (Figure 1). Rice accessions in our panel were classified in six sub-populations: TEJ (Temperate Japonica), IND (Indica), AUS (aus), ARO (Aromatic), TRJ (Tropical Japonica), and ADMIX according to Zhao et al. (2011). The amount of the studied monosaccharides for each subpopulation is shown in supplementary Figure S1. The broad-sense heritability $\left(\mathrm{h}_{\mathrm{b}}{ }^{2}\right)$ for the traits ranged from 0.724 for arabinose to 0.976 for fucose content, indicating that the traits are largely under the control of genotype with a few genes being involved in defining the cell wall polysaccharide contents in whole grain and the environment has a minimal effect.

\section{Population Stratification}

The diversity level and stratification of the population were examined before performing GWAS. A kinship matrix summarized the distribution of pairwise relative relationship coefficients among the accessions in the association panel based on SNPs information (Figure 2). A phylogenetic tree and heat map of the values in the kinship matrix created from the SNPs, which both show relatedness among the population as calculated using GAPIT (Figure 2). The results show that there are six subpopulations in the association mapping panel.

\section{Marker-Trait Association (MTA) Analysis}


In order to identify genetic loci responsible for variation in monosaccharide content in rice accessions, GWAS was carried out on a highquality SNP dataset. The Manhattan plots for six monosaccharides were shown in Figure 3. Forty eight significant SNP markers arranged in 19 genomic regions (QTLs) were identified to be associated with monosaccharide contents by Bayesian-information and Linkage-disequilibrium Iteratively Nested Keyway (Blink) model (Figure 3). For arabinose, 2 QTLs each tagged to one SNP were identified which located on chromosomes 3 and 11; the QTL most strongly associated with arabinose was located on chromosome 11 at position 1.51 Mbp (Table 1). For xylose, three genomic regions, tagged by four SNP markers were identified; the strongest QTL was located on chromosome 7 at position 22.16 Mbp (Table 1). For mannose, two significant SNP markers were identified in two genomic regions both located on chromosome 9; the strongest QTL found on chromosome 9 at position $0.695 \mathrm{Mbp}$ (Table 1). For galactose, six SNPs tagged in four genomic regions on chromosomes 1, 2 and 3 were identified (Table 1). The strongest QTL for galactose locates at position 28.67 Mbp For fucose, four significantly associated SNP markers located on chromosomes 3 were identified, and the strongest SNP on this QTL located at position $36.0 \mathrm{Mbp}$ (Table 1). For rhamnose, seven significantly associated QTLs tagged to 28 SNP markers were found on chromosome 2, 3, 5, 6 and 7; the strongest QTL was on chromosome 2 at position $9.55 \mathrm{Mbp}$ (Table 1). Comparison of the locations of the detected genomic regions in this study (QTLs) and the known reported QTLs for grain yield are shown in

\section{Supplementary Table S2.}

\section{Candidate Genes Involved in Monosaccharide Metabolism}

The genes in the vicinity of the associated SNPs (SNP position $\pm 100 \mathrm{Kbp}$ ) are represented in Supplementary Table S3. Among the collocated genes with the associated SNP markers for each trait, we introduced 32 genes as candidate genes for monosaccharide contents (Table 1). Candidate genes were selected based on whether the function of the genes had been characterized before in rice or other species and whether their functions (putative or verified) are related to monosaccharide content. Significant SNPs identified in GWAS analyses were mapped to the rice genome (annotation project database; https://rapdb.dna.affrc.go.jp/). For arabinose, candidate associated genes were a-arabinofuranosidase, pectinesterase inhibitor, GH16, and a MYB family transcription factor. Candidate genes for xylose were OsFBX256, ethylene-responsive element-binding and a pyruvate kinase. For mannose candidate genes consist of a MYB family transcription factor and $S$-domain receptor-like protein kinase. In the case of galactose, candidate genes were GH16, GH17, a GRAS family transcription factor, glutathione Stransferase and GT8. For fucose we have found five candidate genes, including $\mathrm{GH} 16$, receptor protein kinase, gibberellin 20 oxidase 1, a MYB family transcription factor, and lysine-rich arabinogalactan protein 19. And for rhamnose, we have identified eight genes including OsFBX41, polygalacturonase, pectin esterase, leucine rich repeat family protein, serine/threonine-protein kinase, OsSAUR13 - Auxin-responsive SAUR, a COBRA-like protein precursor, Myo-inositol-1phosphate synthase and Squamosa promoter-binding-like protein 11 (Table 1).

\section{Shared QTLs with more than one monosaccharide content}

Investigation of co-location of the detected QTLs for monosaccharide contents showed that a genomic region on chromosome 3 (carrying qAra3.1 and qFuc3.1, 36 Mbp) corresponds to several candidate genes for both arabinose and fucose contents (Supplementary Tables S2 \& S3).

\section{Expression and Co-expression Analyses of Candidate Genes}

Expression data of candidate genes in three tissues (seedling, callus and panicle) using RNA-Seq and TRAP-Seq assays was retrieved from RGAP (ice.plantbiology.msu.edu) and represented in Supplementary Table S4. As seen, according to TRAP-Seq assay the genes LOC_Os11g03780 (alpha-N-arabinofuranosidase), LOC_Os11g03900 (glucosamine-fructose-6-phosphate aminotransferase 1) and LOC_Os03g63970 (gibberellin 20 oxidase 1) associated with arabinose content and LOC_Os02g34560 (plant neutral invertase) associated with rhamnose content, had highest expression in panicles. LOC_Os07g37040 (PB1-containing domain) and LOC_Os02g43870 (inactive receptor kinase) both associated with xylose content, LOC_Os09g01960 (MYB family transcription factor) associated with mannose content, LOC_OsO2g46910 (GH16) and LOC_Os03g51330 (GRAS family transcription factor) associated with galactose content, LOC_Os03g64050 (receptor protein kinase), LOC_Os03g63970 (gibberellin 20 oxidase 1) and LOC_Os03g63540 (lysine-rich arabinogalactan protein 19) associated with fucose content, LOC_Os07g41360 (UDP-arabinopyranose mutase), LOC_Os03g09250 (Myo-inositol-1-phosphate synthase) and LOC_Os06g45310 (Squamosa promoter-binding-like protein 11) associated with rhamnose content, also showed highest expression levels in panicle. Two genes with highest expression levels in seedlings were LOC_Os03g63760: GH16 (associated with arabinose and fucose contents) and LOC_Os02g43850: serine esterase (associated with xylose content) (Supplementary Table S4). 
Networks of co-expressed genes (up to six direct interactions) with the candidate genes were established using RiceFREND (https://ricefrend.dna.affrc.go.jp/) (Supplementary Table S5). For example, in the case of qAra11.1 (carrying a- $N$-arabinofuranosidase), associated with arabinose content, it is co-expressed with only one gene (LOC_Os12g03530: arabinoxylan arabinofuranohydrolase). Among the subset co-expressed genes with co-located genes containing arabinose-associated SNPs, a general presence of kinases is evident. The other co-expressed gene with pectinesterase inhibitor (related to arabinose) is DUF581 that previously was shown to interact with other kinases for their reallocation in nucleus (Nietzche et al. 2014). It seems that a regulatory cascade is present, but its interrelationship with cell monosaccharide content is still missing.

\section{Gene Ontology (GO) and KEGG Analyses}

Gene ontology analysis revealed important features of the candidate genes including cellular component (CC), molecular function (MF) and biological process (BP) (Supplementary Table S5). Cytosol/cytoplasm, membrane/plasma membrane, nucleus and cell wall are the most important targets of proteins/enzymes coded by the candidate genes. Most of candidate genes had one of following molecular functions: transferase activity, hydrolase/catalytic activity, DNA binding activity and kinase activity. In view of biological process, most of genes could be classified in metabolic process class (especially carbohydrate metabolic process and biosynthetic process), nucleic acid metabolic process and cellular/organismal development or organization. KEGG analysis showed that nearly half of the genes had KEGG orthology identifiers (KO), and 11 out of 32 genes had a known pathway; particularly two genes associated with arabinose content including alpha-N-arabinofuranosidase and glucosamine-fructose-6-phosphate aminotransferase 1 and one gene (alpha-1,4glucan-protein synthase) associated with rhamnose content act in a common pathway of amino sugar and nucleotide sugar metabolism (osa00520).

\section{Discussion}

Related QTLs have been reported for arabinose, xylose, mannose, rhamnose, galactose, and fucose in different cereals (Hazen et al. 2003; Stombaugh et al. 2004; Zhang et al. 2012b; Serba et al. 2016; Xu et al. 2017; Warwick Vesztrocy et al. 2018). Since no GWAS has been performed on monosaccharide contents in rice grains, we were motivated to address this gap in the literature, to pave the way for future functional analyses. Association mapping is an effective method for identifying genomic regions that control quantitative traits based on linkage disequilibrium (LD) (Alqudah et al. 2020). In the association mapping method, the resolution and accuracy of the obtained map depend on the extent and the amount of LD decline (Kim et al. 2007; Bastien et al. 2014a, b). LD measures in a mapping population also present an estimation of the number of required markers for the identification of QTLs (Kim et al. 2007; Bastien et al. $2014 \mathrm{a}, \mathrm{b})$. The LD decay in our population was very slow, dropping to 0.2 in around $~ 570 \mathrm{~kb}(\sim 2 \mathrm{cM})$ and to 0.1 in around $1.65 \mathrm{Mbp}(5$ $\mathrm{cM}<$ ) (data not shown). Bioinformatic analysis of trait-associated SNPs is considered a method of choice in identifying candidate genes for multiple complex traits (Liu et al. 2017). Below the association of candidate genes containing the identified markers for each monosaccharide is being discussed.

Arabinose is produced from UDP-Xylose by a UDP-Xyl 4-epimerase (Kotake et al. 2016; Supplementary figure S2). Rhamnogalacturonan I, arabinan, (glucurono)arabinoxylan, xyloglucan (Anders et al. 2012), and arabinogalactan-proteins (Tryfona et al. 2010), all carry arabinose in their structure. Previous studies have shown that a large number of GTs such as GT47, GT64, GT8, GT92 along with methyltransferases and acetyltransferases are involved in pectin biosynthesis (Takenaka et al. 2018). Members of GT families 1, 47, 61, 95 and 77 are involved in the transfer of arabinosyl moieties to acceptor molecules in plants (Harholt et al. 2012; Møller et al. 2017). The arabinose content in our study had an average of $15 \mu \mathrm{g} / \mathrm{mg}$ with heritability $\left(h_{b}{ }^{2}\right)$ of 0.724 . The candidate genes shown to have association with arabinose content were mostly involved in metabolism, catabolism, and phosphoryaltion of carbohydrates and cell wall components (Wu et al., 2016; Marzin et al., 2016; Mouyna et al., 2016). Overexpression of an a-arabinofuranosidase has shown reduction of arabinose and increase in glucose contents for more cellulose accumulation and greater saccharification (Sumiyoshi et al. 2013). Thus, this associated enzyme seems to have a defining role in maintenance of the cell wall network via providing a balance between arabinoxylan and cellulose. In an Arabidopsis line overexpressing pectin methylesterase inhibitor (PMEI), another gene that we show is associated with arabinose content, the amounts of neutral sugars including Arabinose remained unchanged in seeds (Muller et al. 2013). Mutant analysis of an Arabidopsis seed-coat specific PMEl (pmei6) showed pronounced reduction of mucilage (Saez-Aguayo et al. 2013) that is made up of rhamnogalacturonan I decorated with arabinan and galactan modifications (Macquet et al. 2007; Arsovski et al. 2009). PMEl was shown to affect the arabinose content in water-soluble mucilage of Arabidopsis seed coat (SaezAguayo et al. 2013). The rice genome encodes 49 PMEls and their functions have started to be unraveled in recent years (Nguyen et al. 2017). In contrast, overexpression of Aspergillusnidulans pectin methylesterase (AnPME) in Arabidopsisthaliana showed significant increase in arabinose content with significantly less galacturonic acid (Reem et al. 2020). A line of rice over-expressing PMEls (OX- 
OSPMEI28) was shown to have moderate reduction in arabinose next to glucose and xylose in culm tissue, while the rest of neutral sugars remained unchanged (Nguyen et al. 2017). Another candidate gene for arabinose content is glucosamine-fructose-6-phosphate aminotransferase 1 (LOC_Os11g03900, Table 1). Glucosamine-fructose-6-phosphate aminotransferase (GFAT) catalyzes the formation of glucosamine 6-phosphate and is the first and limiting enzyme in the biosynthesis pathway of hexosamine (Yuzwa and Vocadlo, 2014) and this pathway plays important roles in development and growth in plants (Denzel et al. 2014). It has recently been shown that mutations in this gene have been shown to reduce pectin and callus in the Arabidopsis cell wall (Vu et al. 2019). The role of this gene in the metabolism of arabinose has not been studied, but considering that it has been reported that this gene affects the amount of pectin in the cell wall (Vu et al. 2019) and due to Rhamnogalacturonan I in pectin carries arabinose (Anders et al. 2012), it can be assumed that this gene affects the amount of pectin by affecting the amount of arabinose.

Xylose is a pentose that is often used as a food browning agent (Can and Yilmaz 2002). It can chemically be reduced to xylitol (Trivedi et al. 2020), a valuable food additive (Chandel et al. 2018). Xylose is mostly found in xylan polysaccharides. The xylose content in our rice varieties was $18 \mu \mathrm{g} / \mathrm{mg}$ on average with $h_{b}{ }^{2}=0.89$. It has been shown that elongation of the xylan backbone is dependent on the co-operative actions of GT43 (irregular xylem 9 (IRX9), I9H/IRX9-L, IRX14 and I14H/IRX14-L) and GT47 (IRX10 and IRX10-L) enzymes (Jensen et al. 2014, Urbanowicz et al. 2014). A candidate gene found for xylose in our study was a kinase (LOC_Os09g22410, Table 1). Recently, it was shown that a kinase can alter the distribution of hetroxylans and MLGs in elongating sorghum internodes (Oliver et al. 2021).

Mannose is a naturally abundant monosaccharide found in mannan polysaccharides (a minor component in cereal cell walls) and glycoproteins (Kranjčec et al. 2014). Phosphomannose isomerase, phosphomannomutase and GDP-mannose pyrophosphorylase are involved in mannose synthesis (Pourceau et al. 2009). Mannose can be used as a dietary supplement to prevent urinary tract infection (Kranjčec et al. 2014). A reduced form of mannose known as mannitol (Bhatt et al. 2013), is an osmolyte or metabolic store and a powerful scavenger of reactive oxygen species (Meena et al. 2015). Mannose content was $6 \mu \mathrm{g} / \mathrm{mg}$ on average in RWGs, $h_{b}{ }^{2}=0.81$. One of the candidate genes for mannose content was LOC_Os09g02410, S-domain receptor-like kinase (SDRLK; Table 1), which is originally found in self-incompatability responses in Brassica (Zou et al. 2015). Rice has 144 members of SDRLK with varieties of functions in biotic/abiotic stress responses and development (Chen et al. 2013; Fan et al. 2018; Naithani et al. 2021). Transgenic rice plants carrying anti-sense for a member of SDRLK (OSESG1) developed into fewer crown roots and shorter shoots at seedling stage compared to wild type (Pan et al. 2020). In contrast, overexpression of another truncated SDRLK homologue improved plant height and yield components, including primary branches per panicle and grains per primary branch and eventually total yield (Zou et al. 2015). Despite these recent attempts for understanding the function of SDRLKs, no reports have been made towards their possible roles in monosaccharide contents, cell wall structure, and grain composition. When lowering the significance threshold $[-\log 10(p)<4)]$, marginal SNPs were detected to be associated with mannose content (data not shown). One is id3015638 on chromosome 3 (at position $32470502 \mathrm{bp}$ ). A candidate gene near this SNP could be marked probably associated to mannose content, namely Arabinogalactan lysine-rich protein (AGP 19). The cell wall-associated glycopeptides (AGP 17, 18, 19; glycosylphosphatidylinositol (GPI)-plasma membrane anchored proteins) have been shown to be involved in sextual reproduction in flowering plants and as a wall plasticizer for cell expansion, growth and development (Zhang et al. 2011; Verdugo-Perales et al. 2018). In Arabidopsis, agp19 mutants showed fewer siliques and less seed production (Yang et al. 2007). Although, the reason for lesser seed and silique numbers compared to wild type was not clear at the time of publication, we speculate that the monosaccharide homeostasis between source and sink might be the possible reason. More detailed and directed analyses need to be conducted in mutants and overexpressed lines for monosaccharide contents of seeds to describe any relevance of AGPs to these traits.

Galactose is mainly found in arabinogalactan proteins and pectin. Analysis of our rice population showed galactose content to have an average value of $5 \mu \mathrm{g} / \mathrm{mg}$ in RWG with $\mathrm{h}_{\mathrm{b}}{ }^{2}=0.92$. Candidate genes identified as being associated with galactose content were mainly involved in carbohydrate metabolism. GH16 (Sakamoto and Ishimaru, 2013; Kalomoiri et al. 2019), was among the candidate genes for galactose content. GH16 family members target AGPs possibly during the course of germination, but currently no such relation has been established. The other candidate gene was a GRAS family of plant transcription factor (LOC_Os03g51330) that mediate gibberellin (GA) signaling as a GA-depressible repressor; abolishing a-amylase activity in rice aleurone (Fu et al. 2001). The role of GRAS family members in defining monosaccharide grain contents and more specifically galactose is missing. Glutathione $S$-transferase (GST, LOC_Os01g27340) was the other candidate gene in our study for galactose content. During cereal seeds development and germination, they undergo an orchestrated disappearance of cells via programmed cell death (PCD; for details see Domínguez and Cejudo, 2014). Expression of GST among some other genes, including AGPs and extensins, in addition to their role in wall compositional characteristics, are hypothesized as specific features of PCD (Gao and Showalter, 1999; Betekhtin et al. 2018). We speculate that during

Page $7 / 22$ 
PCD and via an indirect process GST may have an effect on AGP, and therefore it can change the rice grain galactose content; something that needs to be investigated latter. LOC_Os03g24510, Glycosyltransferase family 8 (GT8), that contains galacturonosyltransferase, galacturonosyltransferase-like, GATL-related, galactinol synthase, and plant glycogenin-like starch initiation proteins A (PGSIP-A, B, C), was the other candidate gene for galactose content. Details of GT8 family members functions have not been revealed in cereals. However, they have been found to be cell wall-related and stress-inducible via RNA-seq and microarray analysis (Kong et al., 2019). With lowering significance threshold and considering marginal associated SNPs (data not shown) we could recognize a Polycomb group (PcG) of proteins as candidate gene to galactose content on chromosome 8 (tagged to SNP marker ud8001306 at position $15267417 \mathrm{bp);} \mathrm{they} \mathrm{are} \mathrm{involved} \mathrm{in} \mathrm{regulation} \mathrm{of} \mathrm{different} \mathrm{aspects} \mathrm{of} \mathrm{plant} \mathrm{growth} \mathrm{and} \mathrm{development} \mathrm{(Liu} \mathrm{et} \mathrm{al.}$ 2016; Paul et al. 2020). Comparative transcriptome profiling between a rice mutant for PcG (osfie2-1) and wild type determined differentially expressed genes including endosperm starch synthesis and cell division/expansion among others (Liu et al. 2016). Both traits are indicative of the role of PcG on carbohydrate metabolism and possibly cell wall assembly. Similarly, rice knock out mutants and overexpressed lines were suggestive of the roles of two other PcGs in carbon metabolism, early seed development, seed size and quality in rice (Paul et al. 2020). Furthermore, another marginal SNP was detected by GWAS to which were tagged wall-associated kinases (WAKs) on chromosome 1 (id1009852 at position 14905421 bp). Previously and via computational optical-sectioning microscopy, it has been shown that AGP and WAK have regulatory role in a place called plasmalemmal reticulum, the interface between cytoplasm and cell wall (Gens et al. 2000). AGP with its polyhedral arrays and WAKs by presenting interconnection between membrane and cell wall tighten the structure to withstand mechanical stresses (Gens et al. 2000). It has been reported that WAKs are involved in cell elongation and sugar metabolism modulation (Kohorn et al. 2006). However, for the latter the exact mechanism in the grain is lacking.

Fucose is the most popular hexose in the food industry (Shintani 2019). This monosaccharide is a component of sucrose and is highly sweet, leading to applications in the food and beverage industries with health benefits due to low glycemic response (Gueniche and Castiel-Higounenc 2017). Our data showed that rice grains contain fucose with an average of $14 \mu \mathrm{g} / \mathrm{mg}\left(\mathrm{h}_{\mathrm{b}}{ }^{2}=0.97\right)$. Previously, gibberellin 20 oxidases, a candidate gene for fucose content in this study (LOC_Os03g63970), were reported as corresponding QTLs for seed dormancy and pre-harvest sprouting in rice, wheat and barley (Li et al., 2004). In a study beyond seeds, overexpression of the homologous gene from Pinusdensiflora in a hybrid polar and Arabidopsis led to significant increase in glucose and xylose contents, but not other monosaccahrides (Jeon et al. 2016). In transgenic line of switchgrass (Panicumvirgatum L.) overexpressing Knotted1-like transcription factor, increased expression of gibberellin 20 oxidase was noted; suggesting regulatory effect of GA on the transcription factor (Wuddineh et al. 2016). In the transgenic line, the expression of cellulose and hemicellulose biosynthetic genes were altered and release of sugars improved (by $13 \%$ on average for glucose and xylose) towards improving lignocellulosic feedstock compared to the wild type plant. Till now, there is no report on the effect of gibberellin 20 oxidases on fucose content.

Rhamnose, an important constituent of pectic polysaccharides (mainly rhamnogalacturonans), is a deoxy monosaccharide that is widely distributed in bacteria and plants, but is rare in animals (Wang et al. 2009; Jiang et al. 2020). In plants, rhamnose biosynthesis results from the catalytic action of rhamnose synthase using UDP-glucose as a substrate (Jiang et al. 2020). Palmer et al. (2015) showed the presence of pectin in rice grains via immunofluorescence microscopy, here and for the first time in cereals, we have showed that RWG has an average of $3 \mu \mathrm{g} / \mathrm{mg}$ of rhamnose with $h_{b}{ }^{2}=0.95$. Rice has 58 small auxin-up RNAs (SAURs), a candidate gene of rhamnose content (LOC_Os03g18050, Table 1), which are the early auxin-responsive genes with negative regulatory effect on auxin synthesis and transport (Jain et al. 2006; Kant et al. 2009). Constitutive induction of a rice homologue caused growth and seed yield reduction due to lower auxins, and increased sugar contents among some other changes (Kant et al. 2009). However, no relations with specific monosaccharide contents have been established as yet. The other candidate gene to rhamnose content was an invertase (LOC_Os02g34560, Supplementary Table S3). Invertases function in hydrolysis of sucrose and the resulting hexoses later can be sensed by sugar transporters to define monosaccharide utilization to direct growth and development (Sherson et al. 2003). In a transcript analysis of hybrid aspen, an invertase was among the genes with significantly high expression values with possible association to lignocellulose content in developing xylem tissue (Nakahama et al. 2018). The other candidate gene in our study was a COBRA-like protein, LOC_Os07g41320 (COBL; Table 1). In Arabidopsis, analysis of seed coat epidermal cells (also known as mucilage secretory cells) have shown the role of COBL to be involved in mucilage (rhamnogalacturonan I) deposition in addition to their function in crystalline cellulose deposition (Ben-Tov et al. 2015, 2018). Although little to none is known about rice seed mucilage, there are indications of the presence of pectin in grains (Palmer et al. 2015). Therefore, more compositional/structural investigations in addition to functional analysis of $\mathrm{COBL}$ in rice seems to be required in rice grain. Interestingly, CesA5 was among the co-expressors of the candidate genes involved in rhamnose content (Table 1). CesA5, next to COBL, is among the members of a class of proteins that are reported to be involved in redistribution of the pectic components of seed mucilage (Harpaz-Saad et al. 2011; Mendu et al. 2011; Ben-

Page $8 / 22$ 
Tov et al. 2018). In a mutant analysis approach for cob/2, cesa5, and their double mutants (cob/2cesa5), their role in mucilage ray length became evident (Ben-Tov et al., 2018). Another putative candidate gene to rhamnose content is Squamosa promoter-binding-like protein 11 (LOC_Os06g45310, Table 1). The SQUAMOSA PROMOTER BINDING PROTEIN LIKE box (SPL) gene family represents one of the plant-specific zinc finger protein genes, which encode putative plant-specific transcription factor (Li et al. 2020; Agarwal and Lahiri 2020). SPLs play a role in grain quantity and yield, floral period and stress resistance (Tong et al. 2019). So far, 19 OsSPLs have been identified in rice (Yang et al., 2008). ZmSPL11 has been shown to play a role in growth and development in maize grains (Wang et al. 2005). In Arabidopsis, this gene controls the morphological changes associated with root maturation and the reproductive phase (Shikata et al. 2009). SPL11 in rice is involved in the regulation of cell death and flowering (Liu et al. 2015). Another study has shown that mutations in SPL11 increase disease resistance and increase plant resistance to reactive oxygen species (ROS) (Kojo et al. 2006). The relationship of this gene with the amount of monosaccharides in the grain has not been determined. However, due to the effect of this gene on grain yield (Li et al. 2020), it is likely that this transcription factor affects the amount of rhamnose in the grain.

\section{Conclusions}

Here, the genetic diversity of rice genotypes was put under scrutiny for cell wall monosaccharide contents. Several QTLs were identified on different chromosomes, all are reported for first. Candidate genes identified in this study are proposed to directly or indirectly influence monosaccharide contents in the rice grain, and this provides a roadmap for future genetic studies aimed at validating of the role of these candidate genes in affecting the final composition of mature rice grains. In the present study we identified 19 significant quantitative trait loci (QTLs) associated with monosaccharide content in RWG via GWAS in 197 rice accessions. Despite the extensive monosaccharide analysis, we were not able to correlate these data with RWG cell wall polysaccharides due to the complexity in numbers of such molecules and the fact that monosaccharides such as arabinose are found in multiple cell wall polysaccharides. We believe that our data will contribute to future studies of polysaccharide contents in RWG in addition to the identification of genes and proteins involved in biosynthesis, turn over and modification of the major molecular attributes of this entity.

\section{Abbreviations}

GWAS: genome-wide association study; LD: linkage disequilibrium; Blink: Bayesian-information and Linkage-disequilibrium Iteratively Nested Keyway; SNP: single nucleotide polymorphism; QTL: quantitative trait loci; RWG: rice whole grain; GT: glycosyltransferases; GH: glycoside hydrolases; MLG: Mixed-linkage $\beta$-glucans; TEJ: Temperate Japonica; IND: Indica; AUS: aus; ARO: Aromatic; TRJ: Tropical Japonica; $\mathrm{H}_{b}{ }^{2}$ : broad-sense heritability; MTA: marker-trait association; Mbp: mega base pair; Kbp: kilo base pair.

\section{Declarations}

\section{Ethical Approval and Consent to participate}

Not applicable as no animal experiments were involved in the entire project.

\section{Consent for publication}

All the authors have given their consent to publish the manuscript.

\section{Availability of supporting data}

All relevant data have been provided as Tables, Figures with in the text and in the following supplementary data.

\section{Competing interests}

The authors declare that they have no competing interests.

\section{Funding}

Shahid Beheshti University supported the research.

\section{Authors' contributions}


Rahele Panahabadi performed experiments and prepared the draft of manuscript. Lauren S. McKee contributed in monosaccharide measurements, Asadollah Ahmadikhah supervised the research, provided all samples used in the project and contributed in all analyses, Pär K. Ingvarsson contributed in data analysis, Naser Farrokhi co-supervised the research and contributed in gene identification. All authors read and approved the final manuscript.

\section{Acknowledgments}

We acknowledge the following people without whom the completion of this work would not have been possible: Amparo Jiménez Quero of KTH Glycoscience for help with HPAEC-PAD equipment setup, Francisco Vilaplana and Sara Diaz of KTH Glycoscience for valuable discussions and advice in experimental planning. We also acknowledge the help of Dr. Nadali Bagheri at Sari Agricultural Sciences and Natural Resources University, Sari, Iran for providing land for planting rice genotypes.

rker-trait association; Mbp: mega base pair; Kbp: kilo base pair.

\section{References}

1. Agarwal PR, and Lahiri A (2020) Comparative study of the SBP-box gene family in rice siblings. Journal of Biosciences 45(1): 1-17. doi: 10.1007/s12038-020-00048-z.

2. Ahmed W, Butt MS, Dolan K, Sharif MK, Sultan MT, Ullah A, Rashid S (2017) Pasting properties of pectin coated iron-folate fortified basmati rice. Food Processing and Preservation 41(4): e13157. doi: 10.1111/jfpp.13157.

3. Ajmal M, Rao RAK, Anwar S, Ahmad J, Ahmad R (2003) Adsorption studies on rice husk: removal and recovery of Cd (II) from wastewater. Bioresource Technology 86(2): 147-149. doi: 10.1016/S0960-8524(02)00159-1.

4. Alqudah AM, Sallam A, Baenziger PS, Börner A (2020) GWAS: Fast-forwarding gene identification and characterization in temperate cereals: lessons from barley-a review. Journal of Advanced Research 22: 119-135. doi: 10.1016/j.jare.2019.10.013.

5. Anders N, Wilkinson MD, Lovegrove A, Freeman J, Tryfona T, Pellny TK, Weimar T, Mortimer J, Stott K, Baker J, Defoin-Platel M, Shewry P, Dupree P, Mitchell R (2012) Glycosyltransferases in family 61 mediate arabinofuranosyl transfer onto xylan in grasses. PNAS 109(3): 989-993. doi: 10.1073/pnas.1115858109.

6. Anders N, Wilkinson MD, Lovegrove A, Freeman J, Tryfona T, Pellny TK, Weimar T, Mortimer J, Stott K, Baker J, Defoin-Platel M, Shewry P, Dupree P, Mitchell R (2012) Glycosyltransferases in family 61 mediate arabinofuranosyl transfer onto xylan in grasses. PNAS 109(3): 989-993. doi: 10.1073/pnas.1115858109.

7. Arikit S, Wanchana S, Khanthong S, Saensuk C, Thianthavon T, Vanavichit A, Toojinda T (2019) QTL-seq identifies cooked grain elongation QTLs near soluble starch synthase and starch branching enzymes in rice (Oryza sativa L.). Scientific Reports 9(1): 1-10. $10.5772 / 56621$.

8. Arsovski AA, Popma TM, Haughn GW, Carpita NC, McCann MC, Western TL (2009) AtBXL 1 encodes a bifunctional $\beta$-D-xylosidase/ a-L-arabinofuranosidase required for pectic arabinan modification in Arabidopsis mucilage secretory cells. Plant Physiology 150(3): 1219-1234. doi: 10.1104/pp.109.138388.

9. Bae KD, Um TY, Yang WT, Park TH, Hong SY, Kim KM, Chung YS, Yun DJ, Kim H (2020) Characterisation of dwarf and narrow leaf (dnl-4) mutant in rice. Plant Signaling and Behavior. doi: 10.1080/15592324.2020.1849490.

10. Bai X, Luo L, Yan W, Kovi MR, Zhan W, Xing Y (2010) Genetic dissection of rice grain shape using a recombinant inbred line population derived from two contrasting parents and fine mapping a pleiotropic quantitative trait locus qGL7. BMC Genetics 11(1): 1-11. doi: 10.1186/1471-2156-11-16.

11. Bastien M, Poirier P, Lemieux I, Després JP (2014a) Overview of epidemiology and contribution of obesity to cardiovascular disease. Prog Cardiovasc Dis 56(4): 369-381. doi: 10.1016/j.pcad.2013.10.016.

12. Bastien M, Sonah H, Belzile F (2014b) Genome wide association mapping of Sclerotiniasclerotiorum resistance in soybean with a genotyping-by-sequencing approach. Plant Genome 7(1). doi: 10.1186/s12870-020-02401-8.

13. Ben-Tov D, Idan-Molakandov A, Hugger A, Ben-Shlush I, Günl M, Yang B, Björn U, Harpaz-Saad S (2018) The role of COBRA-LIKE 2 function, as part of the complex network of interacting pathways regulating Arabidopsis seed mucilage polysaccharide matrix organization. The Plant Journal 94(3): 497-512. doi: 10.1111/tpj.13871.

14. Ben-Tov, D., Abraham, Y., Stav, S., Thompson, K., Loraine, A., Elbaum, R., Pauly M, Kieber J, Harpaz-Saad S (2015) COBRA-LIKE2, a member of the glycosylphosphatidylinositol-anchored COBRA-LIKE family, plays a role in cellulose deposition in Arabidopsis seed

Page $10 / 22$ 
coat mucilage secretory cells. Plant Physiology 167(3): 711-724. doi: 10.1104/pp.114.240671.

15. Bera J, and Kale DD (2008) Properties of polypropylene filled with chemically treated rice husk. Journal of Applied Polymer Science 110(2): 1271-1279. doi: 10.1002/app.28747.

16. Betekhtin A, Milewska-Hendel A, Chajec L, Rojek M, Nowak K, Kwasniewska J, Wolny E, Kurczynska E, Hasterok R (2018) 5Azacitidine induces cell death in a tissue culture of Brachypodiumdistachyon. International Journal of Molecular Sciences 19(6): 1806. doi: 10.3390/ijms19061806.

17. Bhatt SM, Mohan A, Srivastava SK (2013) Challenges in enzymatic route of mannitol production. International Scholarly Research Notices 2013. doi: 10.5402/2013/914187.

18. Bodie AR, Micciche AC, Atungulu GG, Rothrock Jr MJ, Ricke SC (2019) Current trends of rice milling byproducts for agricultural applications and alternative food production systems. Frontiers in Sustainable Food Systems 3: 47. doi: 10.3389/fsufs.2019.00047.

19. Bouchet B, Alvarado C, Bakan B, Guillon F (2014) The wheat grain contains pectic domains exhibiting specific spatial and development-associated distribution. PloS One 2(9). doi: 10.1371/journal.pone.0089620.

20. Can A and Yilmaz A (2002) Usage of xylose or glucose as non-enzymatic browning agent for reducing ruminal protein degradation of soybean meal. Small Ruminant Research 46(2-3): 173-178. doi: 10.1016/S0921-4488(02)00197-9.

21. Chandel AK, Antunes FA, Terán-Hilares R, Cota J, Ellilä S, Silveira MH, Santose HC, da Silva SS (2018) Bioconversion of hemicellulose into ethanol and value-added products: commercialization, trends, and future opportunities. Advances in Sugarcane Biorefinery 97-134. doi: 10.1016/B978-0-12-804534-3.00005-7.

22. Changrong Y, Hengming LWei D, Jinwen Z, Yuran X, Anyu G, Yonggang Lu, Wei N, Shengli, S, Hua A, Ying L, Lihua Z, Xuebao Y, Ju L, Guangde Lu, Zhenghe L, Wei P, Dinghong Z, Xiaolin L (2020) Genome-wide association study on agronomic traits of temperate japonica rice (Oryza sativa L.). Crop Breeding and Applied Biotechnology 20(1). doi: 10.1590/1984-70332020v20n1a1.

23. Chen LJ, Wuriyanghan H, Zhang YQ, Duan KX, Chen HW, Li QT, Lu X, He SJ, Ma B, Zhang Wk, Lin Q, Chen SY, Zhang JS (2013) An Sdomain receptor-like kinase, OsSIK2, confers abiotic stress tolerance and delays dark-induced leaf senescence in rice. Plant Physiology 163(4): 1752-1765. doi: 10.1104/pp.113.224881.

24. Della,VP, Kühn I, Hotza D (2002) Rice husk ash as an alternate source for active silica production. Materials Letters 57(4): 818-821. doi: 10.1016/S0167-577X(02)00879-0.

25. Denzel MS, Storm NJ, Gutschmidt A, Baddi R, Hinze Y, Jarosch E, Sommer T, Hoppe T, Antebi A (2014) Hexosamine pathway metabolites enhance protein quality control and prolong life. Cell 156(6): 1167-1178. doi: 10.1016/j.cell.2014.01.061.

26. Domínguez F, and Cejudo FJ (2014) Programmed cell death (PCD): an essential process of cereal seed development and germination. Frontiers in Plant Science 5: 366. doi: 10.3389/fpls.2014.00366.

27. Ebringerova A, Hroma'dkova Z, Heinze T (2005) Hemicellulose. In Heinze T, editor: Polysaccharides i, Berlin, Heidelberg, Springer. 167.

28. Esa NM, Ling TB, Peng LS (2013) By-products of rice processing: An overview of health benefits and applications. Rice Research. doi: 10.4172/jrr.1000107.

29. Fan J, Bai P, Ning Y, Wang J, Shi X, Xiong Y, Zhang K, He F, Zhang C, Wang R, Meng X, Zhou J, Wang M, Shirsekar G, Park CH, Bellizzi M, Liu W, Jeon JS, Xia Y, Shan L, Wang GL (2018) The monocot-specific receptor-like kinase SDS2 controls cell death and immunity in rice. Cell Host \& Microbe 23(4): 498-510. doi: 10.1016/j.chom.2018.03.003.

30. Fu X, Sudhakar D, Peng J, Richards DE, Christou P, Harberd NP (2001) Expression of Arabidopsis GAI in transgenic rice represses multiple gibberellin responses. The Plant Cell 13(8): 1791-1802. doi: 10.1105/TPC.010020.

31. Gao M, and Showalter AM (1999) Yariv reagent treatment induces programmed cell death in Arabidopsis cell cultures and implicates arabinogalactan protein involvement. The Plant Journal 19(3): 321-331. doi: 10.1046/j.1365-313X.1999.00544.X.

32. Gens JS, Fujiki M, Pickard BG (2000) Arabinogalactan protein and wall-associated kinase in a plasmalemmal reticulum with specialized vertices. Protoplasma 212(1): 115-134. doi: 10.1007/BF01279353.

33. Gueniche A, Castiel-Higounenc I (2017) Efficacy of glucosamine sulphate in skin ageing: results from an ex vivo anti-ageing model and a clinical trial. Skin Pharmacology and Physiology 30(1): 36-41. doi: 10.1159/000450832.

34. Guillon F, Philippe S, Bouchet B, Devaux MF, Frasse P, Jones B, Bouzayen M, Lahaye M, Lahaye M (2008) Down-regulation of an auxin response factor in the tomato induces modification of fine pectin structure and tissue architecture. Journal of Experimental Botany 59(2): 273-288. doi: 10.1093/jxb/erm323. Epub 2008 Feb 10.

Page $11 / 22$ 
35. Gul K, Yousuf B, Singh AK, Singh P, Wani AA (2015) Rice bran: nutritional values and its emerging potential for development of functional food. Bioactive Carbohydrates and Dietary Fibre 6(1): 24-30. doi: 10.1016/j.bcdf.2015.06.002.

36. Hachem K, Benabdesslem Y, Ghomari S, Hasnaoui O, Kaid-Harche M (2016) Partial structural characterization of pectin cell wall from Argania spinosa leaves. Heliyon 2(2). doi: 10.1016/j.heliyon.2016.e00076.

37. Harholt J, Jensen JK, Verhertbruggen Y, Søgaard C, Bernard S, Nafisi M, Poulsen CP, Geshi N, Sakuragi Y, Driouich A, Knox P, Scheller HV (2012) ARAD proteins associated with pectic Arabinan biosynthesis form complexes when transiently overexpressed in planta. Planta 236(1): 115-128. doi: 10.1007/s00425-012-1592-3.

38. Harpaz-Saad S, McFarlane HE, Xu S, Divi UK, Forward B, Western TL, Kieber JJ (2011) Cellulose synthesis via the FEI2 RLK/SOS5 pathway and cellulose synthase 5 is required for the structure of seed coat mucilage in Arabidopsis. The Plant Journal 68(6): 941953. doi: 10.1111/j.1365-313X.2011.04760.x.

39. Hazen P, Hawley RM, Davis GL, Henrissat B, Walton JD (2003) Quantitative trait loci and comparative genomics of cereal cell wall composition. Plant Physiology 132(1): 263-271. doi: 10.1104/pp.103.020016.

40. Huang M, Liu X, Zhou Y, Summers RM, Zhang Z (2019) BLINK: A package for the next level of genome-wide association studies with both individuals and markers in the millions. Gigascience Giy 154. doi:10.1093/gigascience/giy154.

41. Hui W, Jiayu Z, Farkhanda N, Juan L, Shuangfei S, Guanghua H, Ting Z, Yinghua L, Fangming Z (2020) Identification of rice QTLs for important agronomic traits with long-kernel CSSL-Z741 and three SSSLs. Rice Science 27(5): 414-422. doi: 10.1016/j.rsci.2020.04.008.

42. Itoh T, Tanaka T, Barrero RA, Yamasaki C, Fujii Y, Hilton PB, Sasaki T (2007) Curated genome annotation of Oryzasativa spp. japonica and comparative genome analysis with Arabidopsis thaliana. Genome Research, 17(2): 175-183. doi: 10.1101/gr.5509507.

43. Jacquemin L, Mogni A, Zeitoun R, Guinot C, Sablayrolles C, Saulnier L, Pontalier PY (2015) Comparison of different twin-screw extraction conditions for the production of arabinoxylans. Carbohydrate Polymers 116: 86-94. doi: 10.1016/j.carbpol.2014.06.071.

44. Jain M, Tyagi AK, Khurana JP (2006) Genome-wide analysis, evolutionary expansion, and expression of early auxin-responsive SAUR gene family in rice (Oryza sativa). Genomics 88(3): 360-371. doi: 10.1016/j.ygeno.2006.04.008.

45. Jensen JK, Johnson NR, Wilkerson CG (2014) Arabidopsis thaliana IRX 10 and two related proteins from psyllium and Physcomitrellapatens are xylan xylosyltransferases. Plant J 80(2): 207-215. doi: 10.1111/tpj.12641.

46. Jeon HW, Cho JS, Park EJ, Han KH, Choi YI, Ko JH (2016) Developing xylem-preferential expression of PdGA20ox1, a gibberellin 20oxidase 1 from Pinusdensiflora, improves woody biomass production in a hybrid poplar. Plant Biotechnology Journal 14(4): 11611170. doi: $10.1111 / p b i .12484$.

47. Jiang N, Dillon FM, Silva A, Gomez-Cano L, Grotewold E (2020) Rhamnose in plants-from biosynthesis to diverse functions. Plant Science 110687. doi: 10.1016/j.plantsci.2020.110687.

48. Juliano BO (2016) RICE. Food Science 41-48. doi: 10.1016/B978-0-12-394437-5.00015-2.

49. Kalomoiri P, Holck J, Coulomb L, Boos I, Enemark-Rasmussen K, Spodsberg N, Monrad RN, Clausen MH (2019) Substrate specificity of novel GH16 endo- $\beta-(1 \rightarrow 3)$-galactanases acting on linear and branched $\beta-(1 \rightarrow 3)$-galactooligosaccharides. Journal of Biotechnology 290: 44-52. doi: 10.1016/j.jbiotec.2018.12.006.

50. Kant S, Bi YM, Zhu T, Rothstein SJ (2009) SAUR39, a small auxin-up RNA gene, acts as a negative regulator of auxin synthesis and transport in rice. Plant Physiology 151(2): 691-701. doi: 10.1104/pp.109.143875.

51. Kato T, Segami S, Toriyama M, Kono I, Ando T, Yano M, Kitano Y, Miura K, Iwasaki Y (2011) Detection of QTLs for grain length from large grain rice (Oryzasativa L.). Breeding Science 61(3): 269-274. doi: 10.1270/jsbbs.61.269.

52. Kim JK, Bamba T, Harada K, Fukusaki E, Kobayashi A (2007) Time-course metabolic profiling in Arabidopsisthaliana cell cultures after salt stress treatment. J Exp Bot 58: 415-424. doi: 10.1093/jxb/erl216.

53. Kobayashi A, Genliang B, Shenghai Y, Tomita K (2007) Detection of quantitative trait loci for white-back and basal-white kernels under high temperature stress in japonica rice varieties. Breeding Science 57(2): 107-116. doi: 10.1270/jsbbs.57.107.

54. Kohorn BD and Kohorn SL (2012) The cell wall-associated kinases, WAKs, as pectin receptors. Frontiers in Plant Science 3: 88. doi: 10.3389/fpls.2012.00088.

55. Kohorn BD, Kobayashi M, Johansen S, Friedman HP, Fischer A, Byers N (2006) Wall-associated kinase 1 (WAK1) is crosslinked in endomembranes, and transport to the cell surface requires correct cell-wall synthesis. Journal of Cell Science 119(11): $2282-2290$. doi: $10.1242 /$ jcs.02968.

Page $12 / 22$ 
56. Kojo K, Yaeno T, Kusumi K, Matsumura H, Fujisawa S, Terauchi R, Iba K (2006) Regulatory mechanisms of ROI generation are affected by rice spl mutations. Plant and Cell Physiology 47(8): 1035-1044.

57. Kong W, Gong Z, Zhong H, Zhang Y, Zhao G, Gautam M, Deng X, Liu C, Zhang C, Li, Y. (2019) Expansion and evolutionary patterns of glycosyltransferase family 8 in Gramineae crop genomes and their expression under salt and cold stresses in Oryza sativa ssp. japonica. Biomolecules 9(5): 188. doi: 10.3390/biom9050188.

58. Kotake T, Yamanashi Y, Imaizumi C, Tsumuraya Y (2016) Metabolism of L-arabinose in plants. Plant Research 129(5): 781-792. doi: 10.1007/s10265-016-0834-z.

59. Kozlova LV, Ageeva M, Ibragimova NN, Gorshkova TA (2014) Arrangement of mixed-linkage glucan and glucuronoarabinoxylan in the cell walls of growing maize roots. Annals of Botany 114(6): 1135-1145. doi: 10.1093/aob/mcu125.

60. Kranjčec B, Papeš D, Altarac S (2014) D-mannose powder for prophylaxis of recurrent urinary tract infections in women: a randomized clinical trial. World journal of urology 32(1): 79-84. doi: 10.1007/s00345-013-1091-6.

61. Kumar U, and Bandyopadhyay M (2006) Sorption of cadmium from aqueous solution using pretreated rice husk. Bioresource Technology 97(1): 104-109. doi: 10.1016/j.biortech.2005.02.027.

62. Li C, Ni P, Francki M, Hunter A, Zhang Y, Schibeci D, Li H, Tarr A, Wang J, Cakir M, Yu J, Bellgard M, Lance R, Appels R (2004) Genes controlling seed dormancy and pre-harvest sprouting in a rice-wheat-barley comparison. Functional \& Integrative Genomics 4(2): 84-93. doi: 10.1007/s10142-004-0104-3.

63. Li Y, Song Q, Zhang Y, Li Z, Guo J, Chen X, Zhang G (2020) Genome-wide identification, characterization, and expression patterns analysis of the SBP-box gene family in wheat (Triticum aestivum L.). Scientific reports 10(1): 1-14. doi: 10.1038/s41598-02074417-x.

64. Li, Y., Xiao, J., Chen, L. Huang, X., Cheng, Z., Han, B., Zhang, Q., Wu, C., Wu, C. (2018). Rice functional genomics research: past decade and future. Molecular Plant, 11(3): 359-380.

65. Lipka AE, Tian F, Wang Q, Peiffer J, Li M, Bradbury PJ, Gore MA, Buckler ES, Zhang ZW (2012) GAPIT: genome association and prediction integrated tool. Bioinformatics 28(18): 2397-9. doi: 10.1093/bioinformatics/bts444.

66. Liu J, Park CH, He F, Nagano M, Wang M, Bellizzi M, Zhang K, Zeng X, Liu, W, Ning Y, Kawano Y, Wang GL (2015) The RhoGAP SPIN6 associates with SPL11 and OsRac1 and negatively regulates programmed cell death and innate immunity in rice. PLoS Pathog 11(2): e1004629. doi: 10.1371/journal.ppat.1004629.

67. Liu X, Wei X, Sheng Z, Jiao G, Tang S, Luo J, Hu P (2016) Polycomb protein OsFIE2 affects plant height and grain yield in rice. PloS One 11(10): e0164748. doi: 10.1371/journal.pone.0164748.

68. Liu Y, Lin Y, Gao S, Li Z, Ma J, Deng M (2017) A genome-wide association study of 23 agronomic traits in Chinese wheat landraces. Plant J 91: 861-873. doi: 10.1111/tpj.13614.

69. Macquet A, Ralet MC, Loudet O, Kronenberger J, Mouille G, Marion-Poll A, North HM (2007) A naturally occurring mutation in an Arabidopsis accession affects a $\beta$-D-galactosidase that increases the hydrophilic potential of rhamnogalacturonan I in seed mucilage. The Plant Cell 19(12): 3990-4006. doi: 10.1105/tpc.107.050179.

70. Marzin S, Hanemann A, Sharma S, Hensel G, Kumlehn J, Schweizer G, Röder MS (2016) Are PECTIN ESTERASE INHIBITOR genes involved in mediating resistance to Rhynchosporiumcommune in barley?. PloS One 11(3): e0150485. doi: $10.1371 /$ journal.pone.0150485.

71. Mather KA, Caicedo AL, Polato NR, Olsen KM, McCouch S, Purugganan MD (2007). The extent of linkage disequilibrium in rice (Oryza sativa L.). Genetics 177(4): 2223-32. doi: 10.1534/genetics.107.079616.

72. McCullagh and Nelder JA (1989) Generalized linear models. 2nd Edition Chapman and Hall. London, UK.8-113 .

73. Meena M, Prasad V, Zehra A, Gupta VK, Upadhyay RS (2015) Mannitol metabolism during pathogenic fungal-host interactions under stressed conditions. Frontiers in Microbiology 6: 1019. doi: 10.3389/fmicb.2015.01019.

74. Mendu V, Griffiths JS, Persson S, Stork J, Downie AB, Voiniciuc C, Haughn GW, DeBolt S (2011) Subfunctionalization of cellulose synthases in seed coat epidermal cells mediates secondary radial wall synthesis and mucilage attachment. Plant Physiology 157(1): 441-453. doi: 10.1104/pp.111.179069.

75. Moongngarm A, Daomukda N, Khumpika S (2012) Chemical compositions, phytochemicals, and antioxidant capacity of rice bran, rice bran layer, and rice germ. Apcbee Procedia 2: 73-79. 10.1016/j.apcbee.2012.06.014.

76. Mouyna I, Aimanianda V, Hartl L, Prevost MC, Sismeiro O, Dillies MA, Jagla B, Legendre R, Coppee J, Latgé JP (2016) GH16 and GH81 family $\beta-(1,3)$-glucanases in Aspergillusfumigatus are essential for conidial cell wall morphogenesis. Cellular Microbiology

Page $13 / 22$ 
18(9): 1285-1293. doi: $10.1111 / \mathrm{cmi} .12630$.

77. Muller K, Levesque-Tremblay G, Bartels S, Weitbrecht K, Wormit A, Usadel B, Haughn G, Kermode AR (2013) Demethylesterification of cell wall pectins in Arabidopsis plays a role in seed germination. Plant Physiology 161(1): 305-316. doi: 10.1104/pp.112.205724.

78. Møller S R, Yi X, Velásquez SM, Gille S, Hansen PL M, Poulsen CP, Olsen CE, Rejzek M, Parsons H, Yang Z, Wandall HH, Clausen H, Field RA, Pauly M, Estevez JM, Harholt J, Ulvskov P, Petersen BL (2017) Identification and evolution of a plant cell wall specific glycoprotein glycosyl transferase, ExAD. Scientific Reports 7(1): 1-16. doi: 10.1038/srep45341.

79. Naithani S, Dikeman D, Garg P, Al-Bader N, Jaiswal P (2021) Beyond gene ontology (GO): using biocuration approach to improve the gene nomenclature and functional annotation of rice S-domain kinase subfamily. PeerJ 9: e11052. doi: 10.7717/peerj.11052.

80. Nakahama K, Urata N, Shinya T, Hayashi K, Nanto K, Rosa AC, Kawaoka A (2018) RNA-seq analysis of lignocellulose-related genes in hybrid Eucalyptus with contrasting wood basic density. BMC Plant Biology 18(1): 1-12. doi: 10.1186/s12870-018-1371-9.

81. Nevame AY, Emon RM, Malek MA, Hasan MM, Alam M, Muharam FM, Ismail MR (2018) Relationship between high temperature and formation of chalkiness and their effects on quality of rice. BioMed Research International 2018. doi: 10.1155/2018/1653721.

82. Nguyen HP, Jeong HY, Jeon SH, Kim D, Lee C (2017) Rice pectin methylesterase inhibitor28 (OsPMEI28) encodes a functional PMEI and its overexpression results in a dwarf phenotype through increased pectin methylesterification levels. Journal of Plant Physiology 208: 17-25. doi: 10.1016/j.jplph.2016.11.006.

83. Nietzsche M, SchießI I, Börnke F (2014). The complex becomes more complex: protein-protein interactions of snRK1 with DUF581 family proteins provide a framework for cell- and stimulus type-specific SnRK1 signaling in plants. Front Plant Sci 5: 54. doi: $10.3389 /$ fpls.2014.00054.

84. Okuda M (2019). Rice used for Japanese sake making. Bioscience, Biotechnology, and Biochemistry 83(8): 1428-1441. doi: 10.1080/09168451.2019.1574552.

85. Oliver J, Fan M, McKinley B, Zemelis-Durfee S, Brandizzi F, Wilkerson C, Mullet JE (2021) The AGCVIII kinase Dw2 modulates cell proliferation, endomembrane trafficking, and MLG/xylan cell wall localization in elongating stem internodes of Sorghumbicolor. The Plant Journal 105(4): 1053. doi: 10.1111/tpj.15086.

86. Palmer R, Cornuault V, Marcus SE, Knox JP, Shewry PR, Tosi P (2015) Comparative insitu analyses of cell wall matrix polysaccharide dynamics in developing rice and wheat grain. Planta 241(3): 669-685. doi: 10.1007/s00425-014-2201-4.

87. Pan J, Li Z, Wang Q, Yang L, Yao F, Liu W (2020) An S-domain receptor-like kinase, OsESG1, regulates early crown root development and drought resistance in rice. Plant Science 290: 110318. doi: 10.1016/j.plantsci.2019.110318.

88. Panahabadi R, Ahmadikhah A, McKee LS, Ingvarsson PK, Farrokhi N (2021) Genome-wide association mapping of mixed linkage $(1,3 ; 1,4)-\beta$-glucan and starch content in rice whole grain. Frontiers in Plant Science. Accepted.

89. Paul P, Dhatt BK, Miller M, Folsom JJ, Wang Z, Krassovskaya I, Liu K, Sandhu J, Yu H, Zhang C, Obata T, Staswick P, Walia H (2020) MADS78 and MADS79 are essential regulators of early seed development in rice. Plant Physiology 182(2): 933-948. doi: 10.1104/pp.19.00917.

90. Pourceau G, Meyer A, Vasseur JJ, Morvan F (2009) Synthesis of mannose and galactose oligonucleotide conjugates by bi-click chemistry. The Journal of Organic Chemistry 74(3): 1218-1222. doi: 10.1021/jo802536q.

91. Project IRGS (2005) The map-based sequence of the rice genome. Nature 436(7052): 793-800. doi: 10.1038/nature03895.

92. Razavi NM, Jafarzadeh DF, Ouroumiehei AA, Ershad LA (2006) Mechanical properties and water absorption behaviour of chopped rice husk filled polypropylene composites. Iranian Polymer Journal 15(9): 757-766.

93. Reem NT, Chambers L, Zhang N, Abdullah SF, Chen Y, Feng G, Gao S, Soto-Burgos J, Pogorelko G, Bassham DC, Anderson CT, Walley JW, Zabotina OA (2020) Post-synthetic reduction of pectin methylesterification causes morphological abnormalities and alterations to stress response in Arabidopsisthaliana. Plants, 9(11): 1558. doi: 10.3390/plants9111558.

94. Saez-Aguayo S, Ralet MC, Berger A, Botran L, Ropartz D, Marion-Poll A, North HM (2013) PECTIN METHYLESTERASE INHIBITOR6 promotes Arabidopsis mucilage release by limiting methylesterification of homogalacturonan in seed coat epidermal cells. The Plant Cell 25(1): 308-323. doi: 10.1105/tpc.112.106575.

95. Sakamoto T, and Ishimaru M (2013) Peculiarities and applications of galactanolytic enzymes that act on type I and II arabinogalactans. Applied Microbiology and Biotechnology 97(12): 5201-5213. doi: 10.1007/s00253-013-4946-2.

96. Saldívar SOS, Soto FEA (2020) Chemical composition and biosynthesis of dietary fiber components. In Science and Technology of Fibers in Food Systems 15-43. doi: 10.1007/978-3-030-38654-2_2.

97. Saunders RM (1990) The properties of rice bran as a food stuff. Cereal Foods World 35(7): 632-662.

Page $14 / 22$ 
98. Serba DD, Sykes RW, Gjersing EL, Decker SR., Daverdin G, Devos KM, Brummer EC, Saha MC (2016) Cell wall composition and underlying QTL in an F1 pseudo-testcross population of switchgrass. BioEnergy Research 9(3): 836-850. doi: 10.1007/s12155-0169733-3.

99. Shao G, Wei X, Chen M, Tang S, Luo J, Jiao G, Xie L, Hu P (2012) Allelic variation for a candidate gene for GS7, responsible for grain shape in rice. Theoretical and Applied Genetics, 125(6): 1303-1312. doi: 10.1007/s00122-012-1914-7.

100. Sherson SM, Alford HL, Forbes SM, Wallace G, Smith SM (2003) Roles of cell-wall invertases and monosaccharide transporters in the growth and development of Arabidopsis. Journal of Experimental Botany 54(382): 525-531. doi: 10.1093/jxb/erg055.

101. Shibuya N and Nakane R (1984) Pectic polysaccharides of rice endosperm cell walls. Phytochemistry 23(7): 1425-1429. doi: 10.1016/S0031-9422(00)80479-3.

102. Shikata M, Koyama T, Mitsuda N, Ohme-Takagi M (2009) Arabidopsis SBP-box genes SPL10, SPL11 and SPL2 control morphological change in association with shoot maturation in the reproductive phase. Plant and Cell Physiology 50(12): 21332145. doi: $10.1093 /$ pcp/pcp148.

103. Shintani T (2019) Food industrial production of monosaccharides using microbial, enzymatic, and chemical methods. Fermentation 5(2): 47. doi: 10.3390/fermentation5020047.

104. Shrotri A, Kobayashi H, Fukuoka A (2017) Catalytic conversion of structural carbohydrates and lignin to chemicals. Advances in Catalysis 60: 59-123. doi: 10.1016/bs.acat.2017.09.002.

105. Singh R, Singh AK, Sharma TR, Singh A, Singh NK (2012) Fine mapping of grain length QTLs on chromosomes 1 and 7 in Basmati rice (Oryza sativa L.). Journal of Plant Biochemistry and Biotechnology 21(2): 157-166. doi: 10.1007/s13562-011-0080-3.

106. Stombaugh SK, Orf JH, Jung HG, Chase K, Lark KG, Somers DA (2004) Quantitative trait loci associated with cell wall polysaccharides in soybean seed. Crop Science 44(6): 2101-2106. doi: 10.2135/cropsci2004.2101.

107. Sumiyoshi M, Nakamura A, Nakamura H, Hakata M, Ichikawa H, Hirochika H, Ishii T, Satoh S, Iwai H (2013) Increase in cellulose accumulation and improvement of saccharification by overexpression of arabinofuranosidase in rice. PLoS One 8(11): e78269. doi: 10.1371/journal.pone.0078269.

108. Takenaka Y, Kato K, Ogawa-Ohnishi M, Tsuruhama K, Kajiura H, Yagyu K, Takeda A, Takeda Y, Kunieda T, Hara-Nishimura I, Kuroham T, Nishitani K, Matsubayashi Y, Ishimizu T (2018) Pectin RG-I rhamnosyltransferases represent a novel plant-specific glycosyltransferase family. Nature Plants 4(9): 669-676. doi: 10.1038/s41477-018-0217-7.

109. Tong T, Fang Y, Zhang Z, Zheng J, Lu X, Zhang X, Xue D (2020) Genome-wide identification, phylogenetic and expression analysis of SBP-box gene family in barley (Hordeum vulgare L.). Plant Growth Regulation 90(1): 137-149. doi: 10.1007/s10725-019-005592.

110. Trivedi J, Bhonsle AK, Atray N (2020) Processing food waste for the production of platform chemicals. In Refining Biomass Residues for Sustainable Energy and Bioproducts 427-448. doi: 10.1016/B978-0-12-818996-2.00019-3.

111. Tryfona T, Liang HC, Kotake T, Kaneko S, Marsh J, Ichinose H, Lovegrove A, Tsumuraya Y, Shewry RP, Stephens E, Dupree P (2010) Carbohydrate structural analysis of wheat flour arabinogalactan protein. Carbohydrate Research 345(18): 2648-2656. doi: 10.1016/j.carres.2010.09.018

112. Upadhyay A and Karn S K (2018) Brown rice: nutritional composition and health benefits. Food Science and Technology Nepal 10: 47-52. doi:10.3126/JFSTN.V10I0.19711.

113. Urbanowicz BR, Peña MJ, Moniz HA, Moremen KW, York WS (2014). Two Arabidopsis proteins synthesize acetylated xylan in vitro. Plant J 80(2): 197-206. doi: 10.1111/tpj.12643. Epub.

114. Wan XY, Wan JM, Jiang L, Wang JK, Zhai HQ, Weng JF, Wang HL, Lei CL, Wang JL, Zhang X, Cheng ZJ, Guo XP (2006) QTL analysis for rice grain length and fine mapping of an identified QTL with stable and major effects. Theoretical and Applied Genetics 112(7): 1258-1270. doi: 10.1007/s00122-006-0227-0.

115. Wang H, Nussbaum-Wagler T, Li B, Zhao Q, Vigouroux Y, Faller M, Bomblies K, Lukens L, Doebley JF (2005) The origin of the naked grains of maize. Nature, 436(7051): 714-719. doi: 10.1038/nature03863.

116. Wang J, Ji Q, Jiang L, Shen S, Fan Y, Zhang C (2009) Overexpression of a cytosol-localized rhamnose biosynthesis protein encoded by Arabidopsis RHM1 gene increases rhamnose content in cell wall. Plant Physiology and Biochemistry 47(2): 86-93. doi: 10.1016/j.plaphy.2008.10.011.

117. Verdugo-Perales M, Velez-de la Rocha R, León-Félix J, Osuna-Enciso T, Heredia JB, Osuna-Castro JA, A. Lslas-Osuna M, SañudoBarajas JA (2018) Gene expression of an arabinogalactan lysine-rich protein Ca AGP18 during vegetative and reproductive 
development of bell pepper (Capsicum annuum L.). 3 Biotech 8(1), 1-9. doi: 10.1007/s13205-017-1031-z.

118. Vidal R, Martínez P, Garraín D (2009) Life cycle assessment of composite materials made of recycled thermoplastics combined with rice husks and cotton linters. The International Journal of Life Cycle Assessment 14(1): 73-82. doi: 10.1007/s11367-008-00437.

119. Wilson TA, Idreis HM, Taylor CM, Nicolosi RJ (2002) Whole fat rice bran reduces the development of early aortic atherosclerosis in hypercholesterolemic hamsters compared with wheat bran. Nutr Res 22: 1319-1332. doi: 10.1016/S0271-5317(02)00438-4.

120. Wu J, Wang Y, Park SY, Kim SG, Yoo JS, Park S, Gupta R, Kang K u, Kim ST (2016) Secreted alpha-N-arabinofuranosidase B protein is required for the full virulence of Magnaporthe oryzae and triggers host defences. PLoS One 11(10): e0165149. doi: 10.1371/journal.pone.0165149.

121. Vu KV, Jeong CY, Nguyen TT, Dinh TT H, Lee H, Hong SW (2019) Deficiency of AtGFAT1 activity impairs growth, pollen germination and tolerance to tunicamycin in Arabidopsis. Journal of Experimental Botany 70(6): 1775-1787. doi: 10.1093/jxb/erz055.

122. Wuddineh WA, Mazarei M, Zhang JY, Turner GB, Sykes RW, Decker SR, Davis M, Udvardi MK, Stewart Jr CN (2016) Identification and overexpression of a Knotted1-like transcription factor in switchgrass (Panicum virgatum L.) for lignocellulosic feedstock improvement. Frontiers in Plant Science 7: 520. doi: 10.3389/fpls.2016.00520.

123. Xu JJ, Zhang XF, Xue HW (2016) Rice aleurone layer specific OsNF-YB1 regulates grain filling and endosperm development by interacting with an ERF transcription factor. Experimental Botany erw409. doi: 10.1093/jxb/erw409.

124. Xu Z, Li S, Zhang C, Zhang B, Zhu K, Zhou Y, Liu Q (2017) Genetic connection between cell-wall composition and grain yield via parallel QTL analysis in indica and japonica subspecies. Scientific Reports 7(1): 1-13. doi: 10.1038/s41598-017-12903-5.

125. Yang J, Sardar HS, McGovern KR, Zhang Y, Showalter AM (2007) A lysine-rich arabinogalactan protein in Arabidopsis is essential for plant growth and development, including cell division and expansion. The Plant Journal 49(4): 629-640. doi: 10.1111/j.1365313X.2006.02985.x.

126. Yang Y, Rao Y, Xu J, Shao G, Leng Y, Huang L, Wang L, Dai L, Zhang G, Hu J, Zhu L, Li C, Gao Z, Guo L, Qian Q, Zeng, D (2014) Genetic analysis of sugar-related traits in rice grain. South African Journal of Botany 93: 137-141. doi: 10.1016/j.sajb.2014.03.013.

127. Yang Z, Wang X, Gu S, Hu Z, Xu H, Xu C (2008) Comparative study of SBP-box gene family in Arabidopsis and rice. Gene 407(1-2): 1-11. doi: 10.1016/j.gene.2007.02.034.

128. Yussuf AA, Massoumi I, Hassan A (2010) Comparison of polylactic acid/kenaf and polylactic acid/rise husk composites: the influence of the natural fibers on the mechanical, thermal and biodegradability properties. Journal of Polymers and the Environment 18(3): 422-429. doi: 10.1007/s10924-010-0185-0.

129. Yuzwa SA, Vocadlo DJ (2014) O-GIcNAc and neurodegeneration: biochemical mechanisms and potential roles in Alzheimer's disease and beyond. Chemical Society Reviews 43(19): 6839-6858. doi: 10.1039/C4CS00038B.

130. Zemke N, Woods E (2009) Rice husk ash. California Polytechnic State University. pp. 1-2.

131. Zhang SJ, Song XQ, Yu BS, Zhang BC, Sun CQ, Knox JP, Zhou YH (2012b) Identification of quantitative trait loci affecting hemicellulose characteristics based on cell wall composition in a wild and cultivated rice species. Molecular Plant 5(1): 162-175. doi: $10.1093 / \mathrm{mp} / \mathrm{ssr} 076$.

132. Zhang Y, Yang J, Showalter AM (2011) AtAGP18, a lysine-rich arabinogalactan protein in Arabidopsisthaliana, functions in plant growth and development as a putative co-receptor for signal transduction. Plant Signaling \& Behavior 6(6): 855-857. doi: 10.4161/psb.6.6.15204.

133. Zhang Z, Ersoz E, Lai CQ, Todhunter RJ, Tiwari HK, Gore MA, Buckler ES (2010) Mixed linear model approach adapted for genomewide association studies. Nature Genetics 42(4): 355-360. doi: 10.1038/ng.546.

134. Zhang Z, Khan NM, Nunez KM, Chess EK, Szabo CM (2012a) Complete monosaccharide analysis by high-performance anionexchange chromatography with pulsed amperometric detection. Analytical Chemistry 84(9). doi: 10.1021/ac300176z.

135. Zhao K, Tung W, Eizenga C, Wright H, Ali L, Price H, Norton J, Islam R, Reynolds A, Mexey J, McClung A, Bustamante D, Mccouch S (2011) Genome-wide association mapping reveals a rich genetic architecture of complex traits in Oryza sativa L. Nature Communications 2(1): 1-10. doi: 10.1038/ncomms1467.

136. Zhou L, Chen L, Jiang L, Zhang W, Liu L, Liu X, Zhao Z, Liu S, Zhang L, Wan J (2009) Fine mapping of the grain chalkiness QTL qPGWC-7 in rice (Oryza sativa L.). Theoretical and Applied Genetics 118(3): 581-590. doi: 10.1007/s00122-008-0922-0.

137. Zou X, Qin Z, Zhang C, Liu B, Liu J, Zhang C, Liu B, Liu J, Zhang C, Lin C, Li, H, Zhao, T (2015) Over-expression of an S-domain receptor-like kinase extracellular domain improves panicle architecture and grain yield in rice. Journal of Experimental Botany 
66(22): 7197-7209. doi: 10.1093/jxb/erv417.

\section{Tables}

TABLE 1 SNPs associated with monosaccharide content, and the putative candidate genes in 100 Kbp flanking window. 


\begin{tabular}{|c|c|c|c|c|c|c|c|c|}
\hline Trait & QTL & Chr. & $\begin{array}{l}\text { No. of } \\
\text { associated } \\
\text { markers }\end{array}$ & $\begin{array}{l}\text { Peak } \\
\text { marker }\end{array}$ & $\begin{array}{l}\text { Position } \\
\text { (bp) }\end{array}$ & $\begin{array}{l}\operatorname{fog}_{10} \\
\text { ( } \mathrm{p}- \\
\text { value) }\end{array}$ & Candidate gene(s) & $\begin{array}{l}\text { Co-expressed gene } \\
\text { list obtained by } \\
\text { Genevestigator }\end{array}$ \\
\hline \multirow[t]{5}{*}{ Arabinose } & qAra11.1 & 11 & 1 & id11000413 & 1512711 & 5.07 & $\begin{array}{l}\text { LOC_Os11g03780 (a- } \\
N^{-} \\
\text {arabinofuranosidase) }\end{array}$ & $\begin{array}{l}-1,2-\text { fucosidase, } \\
\text { CSLD2, } \\
\text { xylosyltransferase }\end{array}$ \\
\hline & & & & & & & $\begin{array}{l}\text { LOC_Os11g03740 } \\
\text { (pectinesterase } \\
\text { inhibitor) }\end{array}$ & - \\
\hline & & & & & & & $\begin{array}{l}\text { LOC_Os11g03900 } \\
\text { (glucosamine- } \\
\text { fructose-6-phosphate } \\
\text { aminotransferase 1) }\end{array}$ & - \\
\hline & qAra3.1 & 3 & 1 & id3018317 & 36093075 & 4.01 & $\begin{array}{l}\text { LOC_Os03g63760 } \\
(\mathrm{GH} 16)\end{array}$ & CESA7, GH10 \\
\hline & & & & & & & $\begin{array}{l}\text { LOC_Os03g63890 } \\
\text { (MYB family } \\
\text { transcription factor) }\end{array}$ & - \\
\hline \multirow[t]{3}{*}{ Xylose } & qXyl.7.1 & 7 & 1 & id7003701 & 22168519 & 4.28 & $\begin{array}{l}\text { LOC_Os07g37080 } \\
\text { (OsFBX256) }\end{array}$ & - \\
\hline & qXyl2.1 & 2 & 3 & id2011638 & 26453039 & 4.05 & $\begin{array}{l}\text { LOC_Os02g } 43840 \\
\text { (ethylene-responsive } \\
\text { element-binding) }\end{array}$ & $\begin{array}{l}\text { 1,3- } \beta \text {-glucan } \\
\text { synthase, } \beta-D- \\
\text { xylosidase, } \\
\text { xyloglucan } \\
\text { fucosyltransferase, } \\
\text { CSLH2, GH16 }\end{array}$ \\
\hline & qXyl9.1 & 9 & 1 & id9003696 & 13578329 & 4.0 & $\begin{array}{l}\text { LOC_Os09g22410 } \\
\text { (pyruvate kinase) }\end{array}$ & $\begin{array}{l}\text { xylanase inhibitor } \\
\text { 1, GH17 }\end{array}$ \\
\hline \multirow[t]{2}{*}{ Mannose } & qMan9.1 & 9 & 1 & id9000124 & 695046 & 5.46 & $\begin{array}{l}\text { LOC_Os09g01960 } \\
\text { (MYB family } \\
\text { transcription factor) }\end{array}$ & WAK20 \\
\hline & qMan9.2 & 9 & 1 & id9000285 & 1056875 & 4.01 & $\begin{array}{l}\text { LOC_Os09g02410 (S- } \\
\text { domain receptor-like } \\
\text { protein kinase) }\end{array}$ & - \\
\hline \multirow[t]{5}{*}{ Galactose } & qGal2.1 & 2 & 1 & id2012462 & 28675981 & 4.68 & $\begin{array}{l}\text { LOC_Os02g46910 } \\
(\mathrm{GH} 16)\end{array}$ & $\begin{array}{l}\text { GT8, CESA1, } \\
\text { CESA6 }\end{array}$ \\
\hline & qGal3.1 & 3 & 2 & id3013842 & 29367583 & 4.32 & $\begin{array}{l}\text { LOC_Os03g51240 } \\
\text { (GH17) }\end{array}$ & $\begin{array}{l}\text { GH10, } \\
\text { CESA9,CESA4, } \\
\text { CESA7, GH16 }\end{array}$ \\
\hline & & & & & & & $\begin{array}{l}\text { LOC_Os03g51330 } \\
\text { (GRAS family } \\
\text { transcription factor) }\end{array}$ & - \\
\hline & qGal3.2 & 3 & 1 & id3007036 & 13997677 & 4.06 & $\begin{array}{l}\text { LOC_Os03g24510 } \\
\text { (GT8) }\end{array}$ & - \\
\hline & qGal1.1 & 1 & 2 & id1010061 & 15343659 & 4.04 & $\begin{array}{l}\text { LOC_Os01g27340 } \\
\text { (glutathione S- } \\
\text { transferase) }\end{array}$ & - \\
\hline \multirow[t]{3}{*}{ Fucose } & qFuc3.1 & 3 & 4 & id3018228 & 36003997 & 5.16 & $\begin{array}{l}\text { LOC_Os03g63760 } \\
(\mathrm{GH} 16)\end{array}$ & \\
\hline & & & & & & & $\begin{array}{l}\text { LOC_Os03g63540 } \\
\text { (lysine-rich } \\
\text { arabinogalactan } \\
\text { protein 19) }\end{array}$ & UCL \\
\hline & & & & & & & $\begin{array}{l}\text { LOC_Os03g64050 } \\
\text { (receptor protein } \\
\text { kinase) }\end{array}$ & Sucrose synthase \\
\hline
\end{tabular}




\begin{tabular}{|c|c|c|c|c|c|c|c|c|}
\hline & & & & & & & $\begin{array}{l}\text { LOC_Os03g63970 } \\
\text { (gibberellin } 20 \\
\text { oxidase 1) }\end{array}$ & \\
\hline & & & & & & & $\begin{array}{l}\text { LOC_Os03g63890 } \\
\text { (MYB family } \\
\text { transcription factor) }\end{array}$ & - \\
\hline \multirow[t]{10}{*}{ Rhamnose } & qRhm2.1 & 2 & 1 & id2004620 & 9554477 & 18.56 & $\begin{array}{l}\text { LOC_Os02g16760 } \\
\text { (OsFBX41) }\end{array}$ & GH10 \\
\hline & qRhm5.1 & 5 & 5 & id5003970 & 7842142 & 7.52 & $\begin{array}{l}\text { LOC_Os05g14150 } \\
\text { (polygalacturonase) }\end{array}$ & - \\
\hline & qRhm7.1 & 7 & 10 & id7004624 & 24950950 & 7.27 & $\begin{array}{l}\text { LOC_Os07g41650 } \\
\text { (pectinesterase) }\end{array}$ & WAK86 \\
\hline & & & & & & & $\begin{array}{l}\text { LOC_Os07g41320 } \\
\text { (COBRA-like protein } \\
\text { precursor) }\end{array}$ & - \\
\hline & qRhm2.2 & 2 & 8 & id2007990 & 20662314 & 6.09 & $\begin{array}{l}\text { LOC_Os02g34490 } \\
\text { (Leucine Rich Repeat } \\
\text { family protein) }\end{array}$ & - \\
\hline & & & & & & & $\begin{array}{l}\text { LOC_Os02g34430 } \\
\text { (serine/threonine- } \\
\text { protein kinase) }\end{array}$ & CESA5 \\
\hline & & & & & & & $\begin{array}{l}\text { LOC_Os02g34560 } \\
\text { (plant neutral } \\
\text { invertase) }\end{array}$ & - \\
\hline & qRhm3.1 & 3 & 4 & id3005212 & 10058280 & 6.09 & $\begin{array}{l}\text { LOC_Os03g18050 } \\
\text { (OsSAUR13 - Auxin- } \\
\text { responsive SAUR) }\end{array}$ & - \\
\hline & qRhm3.2 & 3 & 1 & id3002864 & 4817318 & 6.09 & $\begin{array}{l}\text { LOC_Os03g09250 } \\
\text { (Myo-inositol-1- } \\
\text { phosphate synthase) }\end{array}$ & - \\
\hline & qRhm6.1 & 6 & 1 & id6015511 & 27364086 & 6.09 & $\begin{array}{l}\text { LOC_Os06g45310 } \\
\text { (Squamosa } \\
\text { promoter-binding-like } \\
\text { protein 11) }\end{array}$ & - \\
\hline
\end{tabular}

\section{Figures}



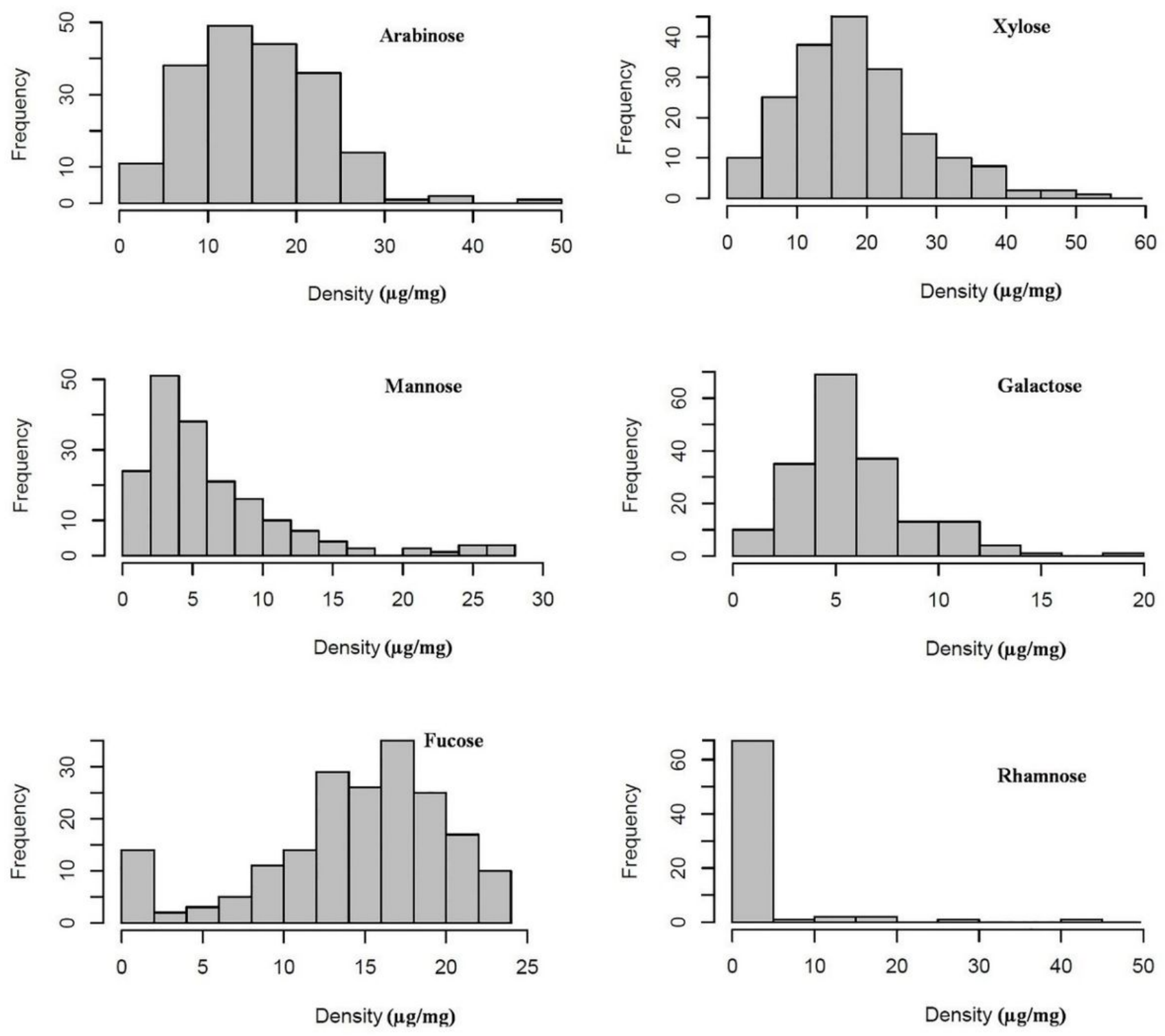

\section{Figure 1}

Phenotypic distribution of selected traits. All values are in micrograms per milligram of dry weight of RWG containing bran ( $\mu \mathrm{g} / \mathrm{mg}$ ). Plots showed a normal distribution between samples, except for mannose and rhamnose that skewed towards low values, and fucose that skewed to higher values. Plot generated using the R program. 

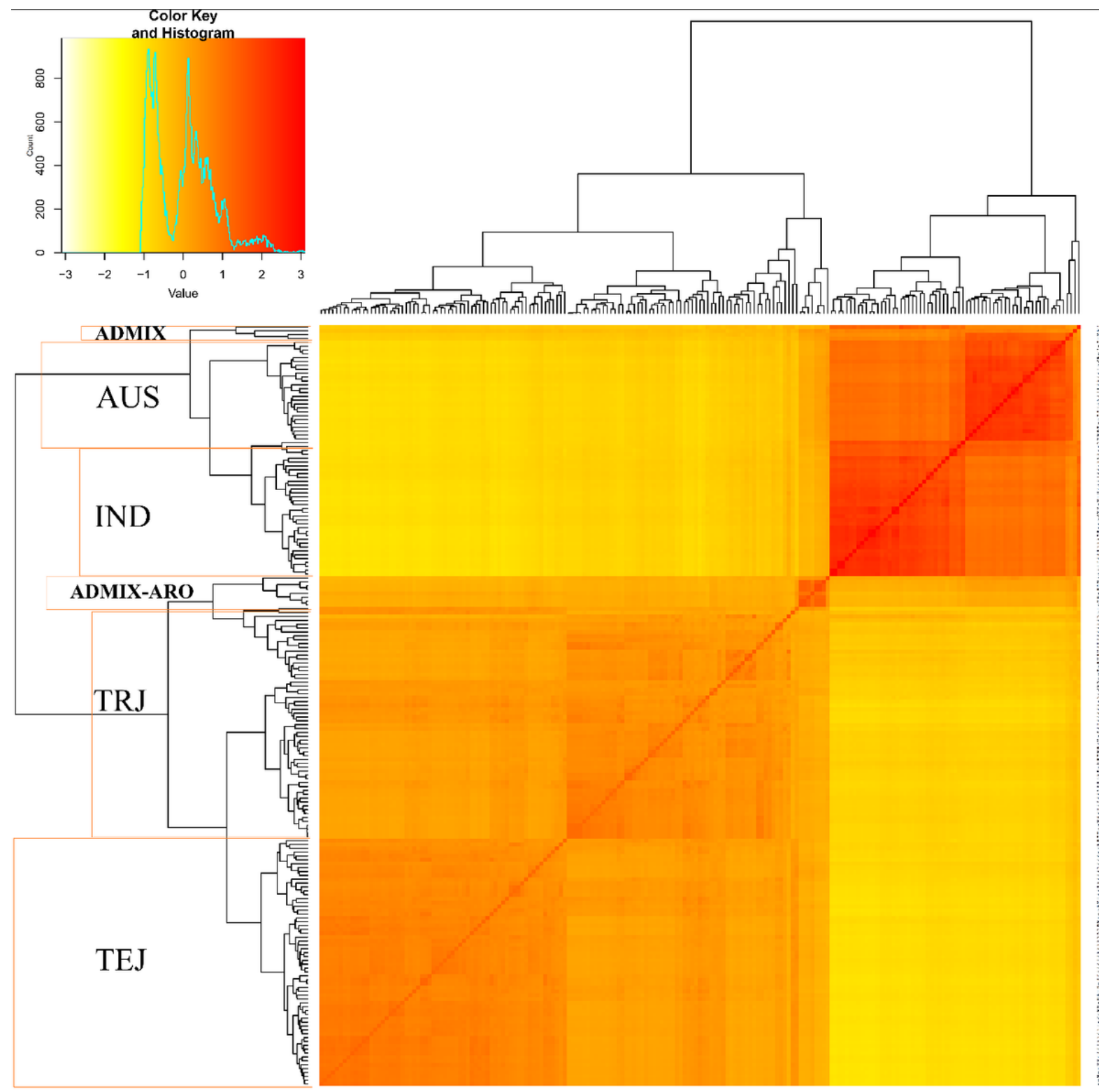

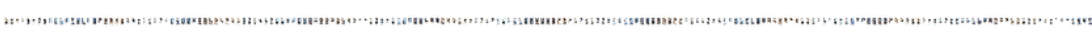

\section{Figure 2}

Heatmap of kinship matrix of 197 rice accessions using SNPs data. Red indicates the highest correlation between pairs of individuals and yellow indicates the lowest correlation. The population is separated into the main six subpopulation. A hierarchical clustering tree based on the pairwise kinship values for all accessions is displayed along the top and left axes. 
a

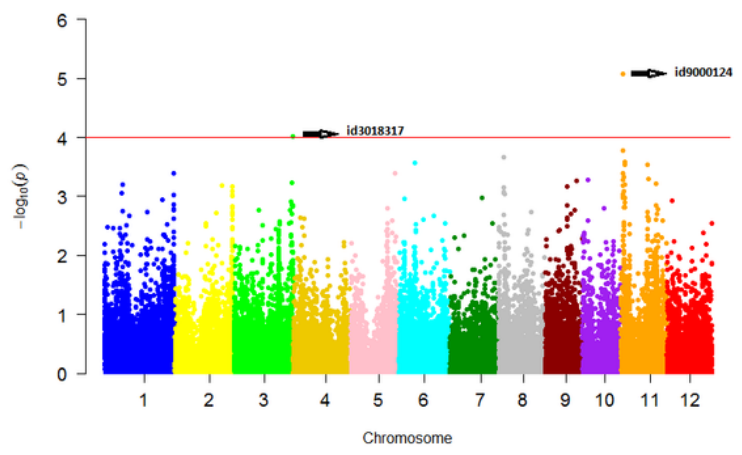

c

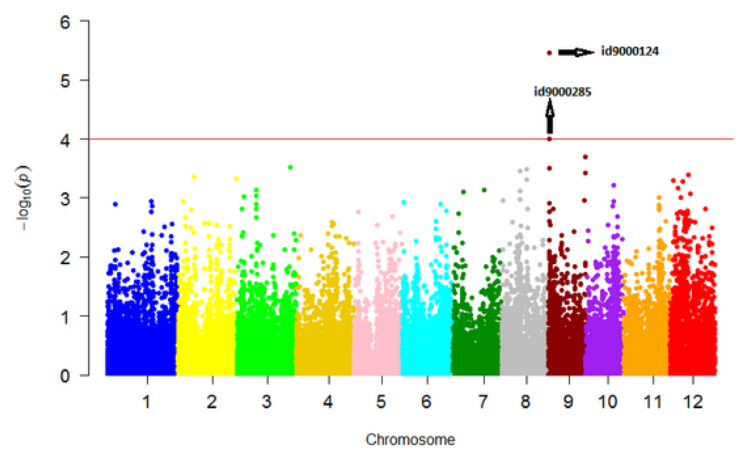

e

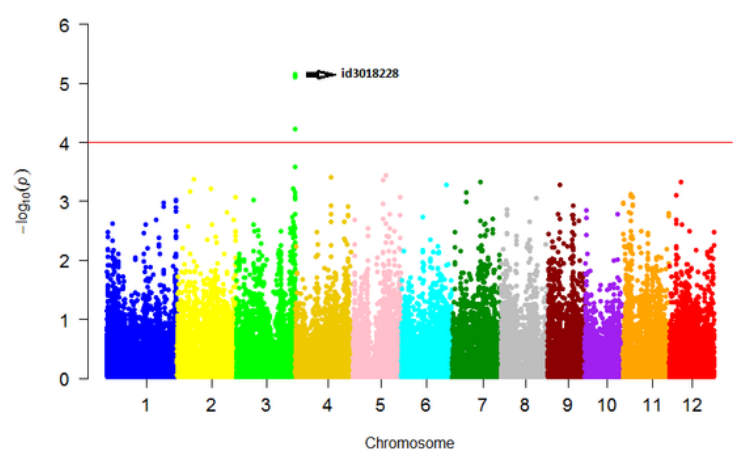

b

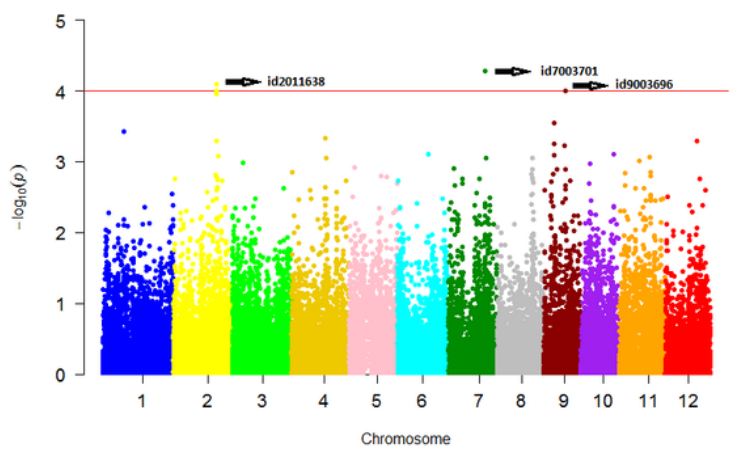

d

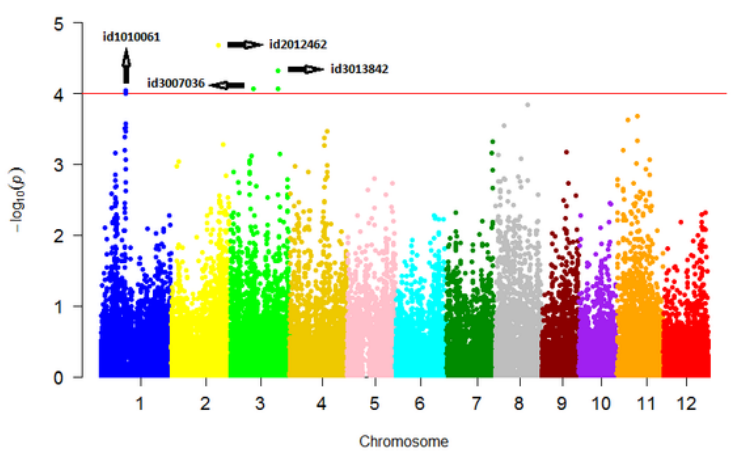

f

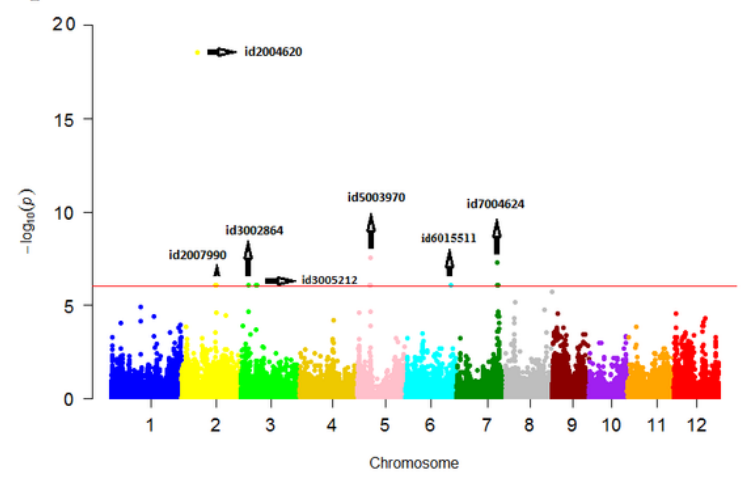

Figure 3

Manhattan plots of grain monosaccharide contents from GWAS using the CMLM model. The -log10 (p-values) from the GWAS are plotted according to genomic position on each of the 12 rice chromosomes on the left side of each Manhattan plot. a) Arabinose, b) Xylose, c) Mannose, d) Galactose, e) Fucose, and f) Rhamnose. Highly significant SNPs on each monosaccharide plot were shown with arrows.

\section{Supplementary Files}

This is a list of supplementary files associated with this preprint. Click to download.

- SupplementaryFiguresS1S2.docx

- SupplimentrayTablesS1S6.xIsx 